

\title{
BUKU AJAR MATA KULIAH FILSAFAT ILMU
}

\author{
Oleh \\ Dr. Nyong ETIS, M.Fil.I.
}

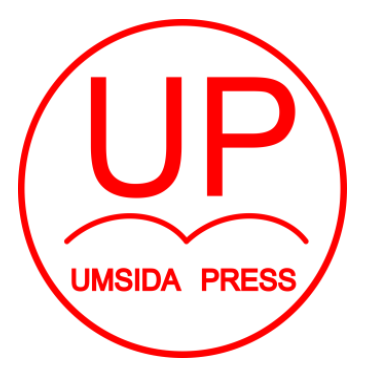

BUKU AJAR

FILSAFAT ILMU

Penulis:

Dr. Nyong ETIS, M.Fil.I.

ISBN:

978-623-7578-21-5

Editor:

Copy Editor:

Design Sampul dan Tata Letak: 


\section{Penerbit:}

UMSIDA Press

\section{Redaksi:}

Universitas Muhammadiyah Sidoarjo

Jl. Mojopahit No 666B

Sidoarjo, Jawa TImur

Cetakan pertama, Agustus 2019

(C) Hak cipta dilindungi undang-undang

Dilarang memperbanyak karya tulis ini dengan suatu apapun tanpa ijin tertulis dari penerbit. 


\section{TINJAUAN MATA KULIAH}

1. Deskripsi Singkat Mata Kuliah

Mata kuliah ini secara garis besar bertujuan mengenalkan filsafat ilmu sebagai suatu disiplin kefilsafatan kepada mahasiswa. Filsafat ilmu adalah suatu kajian sistematis tentang pengetahuan manusia dan justifikasi atau argumentasi atas kebenarannya. Pembahasannya mencakup tentang hakikat ilmu atau pengetahuan ilmiah; apa yang telah dan belum diketahui tentang ilmu; apa yang membedakan ilmu dengan yang bukan ilmu atau pengetahuan; apakah ilmu yang diketahui itu sudah benar; bagaimana awal suatu ilmu dan bagaimana akhirnya; serta apakah kegunaan ilmu. Topik perkuliahan diorganisasikan secara tematis yang diharapkan bisa membantu mempermudah mahasiswa memahami materi kefilsafatan ini berikut penjelasannya serta wawasan kefilsafatan pada umumnya. Proses perkuliahan dibangun untuk membantu mahasiswa mengembangkan kemampuannya berfikir secara filsafati. Berkenaan dengan hal tersebut, maka mata kuliah filsafat ilmu ini didesain untuk memungkinkan seluruh partisipan dapat terlibat secara aktif dan kritis dengan tetap mengedepankan sikap keterbukaan, egalitarian, dan toleran.

2. Kegunaan Mata Kuliah

Filsafat ilmu penting sebagai bekal berpikir filosofis (objektif, sistematis, universal, dan radikal) dalam mencermati berbagai persoalan khususnya ilmu pengetahuan.

\section{Standar Kompetensi}

a. Mahasiswa memiliki wawasan kefilsafatan ilmu.

b. Mahasiswa memiliki keterampilan berpikir filosofis untuk menganalisis persoalan pengetahuan manusia.

\subsection{Kompetensi Dasar}

a. Mahasiswa memahami pengertian filsafat;

b. Mahasiswa memiliki wawasan dan pemahaman tentang kedudukan filsafat di antara ilmu, agama, dan seni;

c. Mahasiswa memahami pengertian filsafat ilmu;

d. Mahasiswa memahami konsep-konsep dasar dan prinsip-prinsip umum dalam filsafat ilmu;

e. Mahasiswa mampu menganalisis fenomena ilmu secara filosofis.

\subsection{Indikator}


a. Mahasiswa dapat menjelaskan pengertian filsafat.

b. Mahasiswa dapat memberikan penjelasan distingtif tentang kedudukan filsafat di antara ilmu, agama, dan seni.

c. Mahasiswa dapat menjelaskan pengertian filsafat ilmu.

d. Mahasiswa dapat menjelaskan konsep-konsep dasar dan prinsip-prinsip umum dalam filsafat ilmu.

e. Mahasiswa dapat menjelaskan fenomena ilmu secara filosofis.

4. Susunan Bahan Ajar

Bahan ajar ini terdiri dari 12 (dua belas) bab di mana masing-masing bab memuat satu tema pokok bahasan yang spesifik. Dalam pembahasan dapat ditemukan pula pola penyajian yang terdiri dari beberapa sub bab untuk memudahkan pemahaman mahasiswa.

5. Petunjuk Bagi Mahasiswa

Untuk membantu mahasiswa dalam mempelajari buku ajar filsafat ilmu ini, dapat dilakukan beberapa tahapan sebagai berikut:

a. Mahasiswa hendaknya membaca dengan teliti narasi pembahasan di setiap bab serta berusaha memahami kandungan isi dan maknanya.

b. Untuk memastikan bahwa pemahaman atas pembahasan di suatu bab memadai, maka cobalah untuk mengerjakan soal yang terdapat pada akhir setiap bab.

c. Lanjutkan membaca dan memahami pembahasan ke bab selanjutnya usai menyelesaikan bacaan dan latihan soal di bab sebelumnya.

d. Meskipun tidak harus secara berturut dari bab awal ke bab akhir, tetapi memahami filsafat ilmu sebagaimana dipaparkan dalam buku ajar ini akan lebih sistematis dan integratif jika dipelajari secara berurutan dari bab pertama lalu berlanjut hingga bab terakhir. pembahasan

e. Agar pemahaman mahasiswa lebih luas dan utuh, maka sangat disarankan agar mereka secara mandiri dapat melengkapi kajiannya dengan referensi lain yang relevan baik dalam bentuk buku teks maupun laporan hasil penelitian dan artikel jurnal ilmiah.

f. 


\section{KATA PENGANTAR}

Buku ini dihadirkan sebagai bacaan pengantar untuk belajar filsafat ilmu. Salah satu bidang kajian kefilsafatan yang tak bisa diabaikan oleh siapapun yang tertarik untuk mendalami dan bergelut di dunia ilmiah. Tulisan ini diharapkan dapat diterima dan bisa member manfaat para pembacanya, khususnya mahasiswa program sarjana yang tengah mengambil mata kuliah filsafat ilmu. Untuk itu, sengaja materi yang disajikan dipilih sesuai dengan tingkatan segmen pembacanya. Struktur penyajian juga sudah diupayakan sedemikian rupa agar sesuai dengan pertemuan perkuliahan mahasiswa sehingga mudah ditelaah dan membantu tugas-tugas mereka.

Melalui buku ini pula penulis berharap bahwa mahasiswa dan pembaca lainnya dapat memetik pengetahuan dan wawasan kefilsafatan ilmu yang memadai, tidak saja dari perspektif keilmuan secara umum, tetapi juga dipadukan dengan wawasan kefilsafatan ilmu dari perspektif Islam. Dengan demikian, mereka akan mendapatkan asupan nalar kritis secara lebih integratif dan holistik. Keterampilan baca mereka tidak semata ditopang dengan paradigm keilmuan yang berbasis kemampuan rasional, tetapi juga dijiwai dengan kemampuan supra-rasional yang bersifat rasional imani.

Terima kasih kepada seluruh pihak yang telah mendukung proses penyusunan buku ini mulai dari awal hingga selesai, terutama Universitas Muhammadiyah Sidoarjo yang telah berkenan untuk memberikan hibah dan menerbitkannya sebagai buku ajar bagi mahasiswa. Semoga segala niat dan ikhtiar baik ini mendapatkan ridha dari Allah Swt. Serta berkontribusi positif bagi pengembangan ilmu pengetahuan dan kemaslahatan umat.

Penulis 


\section{DAFTAR ISI}

Tinjauan Mata Kuliah

Kata Pengantar

Daftar Isi

Bab I Kajian Filsafat

Bab II Filsafat IImu dan Pengetahuan Manusia

Bab III Karakteristik IImu

Bab IV IImu dalam Perspektif Islam

Bab V Dasar-Dasar Pengetahuan Manusia

Bab VI Sikap Dasar Terhadap Pengetahuan dan Kebenaran

Bab VII Struktur Dasar Kegiatan Mengetahui

Bab VIII Pengalaman Inderawi

Bab IX Konseptualisasi

Bab X Kebenaran

Bab XI Etika Ilmiah

DaftarPustaka

Penulis 


\section{BAB I}

\section{KAJIAN FILSAFAT}

\section{PENDAHULUAN}

\subsection{Deskripsi Singkat}

Bab ini merupakan paparan awal mengenai filsafat yang bersifat umum sebagai pengantar menuju diskusi yang lebih khusus mengenai filsafat ilmu. Pada bab ini mahasiswa akan diantar untuk mengenal dan memahami asal-usul, pengertian, ruang lingkup kajian filsafat, serta hubungannya dengan agama, sains, dan seni.

1.2 Relevansi

Melalui bab ini mahasiswa selain memahami pengertian dasar filsafat, juga diharapkan memiliki wawasan kesejarahan sekaligus kedudukan filsafat dalam bangun dunia keilmuan.

\subsection{Kompetensi Dasar}

a. Mahasiswa mampu menggambarkan latar historis perkembangan filsafat.

b. Mahasiswa mampu menjelaskan pengertian filsafat.

c. Mahasiswa mampu menjelaskan ruang lingkup kajian filsafat.

d. Mahasiswa mampu membedakan filsafat dari agama, sains, dan seni.

1.4 Indikator

1. Mahasiswa dapat menjelaskan gambaran latar historis perkembangan filsafat.

2. Mahasiswa dapat menjelaskan pengertian filsafat.

3. Mahasiswa dapat menjelaskan ruang lingkup kajian filsafat.

4. Mahasiswa dapat menjunjukkan distingsi filsafat dari agama, sains, dan seni.

\section{SEJARAH DAN PENGERTIAN FILSAFAT}

Filsafat merupakan kata yang berasal dari istilah dalam bahasa Yunani, philosophia. Secara bahasa filsafat berarti pencinta hikmah atau kebijaksanaan. Tetapi apa sebenarnya yang dimaksud dengan filsafat? Ternyata pemahamannya bisa cukup beragam. Sebagian filsuf ada yang begitu tertarik dengan pembahasan-pembahasan yang sangat abstrak dan tampak sebagai upaya sukar untuk memahami hakikat terakhir alam semesta (proto-ilmiah). Sebagian lagi ada yang lebih melihat filsafat sebagai sesuatu yang bersifat sangat pribadi, sangat sosial dan ramah, sangat praktis berurusan dengan hidup yang baik dan 
ajakan untuk turut melakukannya dalam kehidupan keseharian. Jadi filsafat dalam hal ini berbicara tentang cara hidup, persoalan keadilan dan kebaikan masyarakat (sosiologis-empiris) seperti yang diperbuat Socrates, Buddha dan Konfusius. Kebanyakan filsuf besar seperti Plato dan Aristoteles berupaya untuk menggabungkan dua orientasi kefilsafatan ini (Santosa, 2015).

\subsection{Asal Mula Filsafat}

Filsafat tidak hanya pernah lahir dan tumbuh-kembang di Yunani kuno. la sudah muncul berkali-kali di banyak tempat di belahan bumi ini. Selain Eropa, sukar dipercaya jika aktivitas pemikiran yang serius untuk berspekulasi tentang dunia tidak juga terjadi di benua lainnya seperti Asia, Afrika, Australia, dan juga Amerika. Dari berbagai peradaban besar di wilayah tersebut semisal India, Cina, Babilonia, Inca, Maya, dan Aztec, kuat diduga bahwa suatu bentuk tradisi kefilsafatan juga telah menjadi bagian dari sistem hidup mereka. Maka dari itu, sebagaimana diingatkan Solomon \& Higgins (2002), perlu sikap menghargai ragam tradisi kefilsafatan yang ada tanpa harus berasumsi bahwa suatu versi kurang 'filosofis' atau kurang 'imajinatif' dibandingkan dengan versi lainnya.

Dalam tradisi kefilsafatan Barat, secara historis, awal mula filsafat dapat dikembalikan ke kisaran waktu antara 585 SM - 529 M. Periode ini biasanya dikenal sebagai masa perkembangan filsafat Yunani kuno. Jadi, sejak abad ke-6 SM tersebut, pemikiran manusia menunjukkan arah perkembangan baru yang berbeda dari masa-masa sebelumnya. Mereka mulai aktif berfikir dan mengkaji tentang dunia dan diri mereka sendiri dimana aspek-aspek fundamendalnya dapat diketemukan dalam peradaban Barat dewasa ini. Sementara pelarangan pengajaran filsafat Yunani (Greek philosophy) di Athena pada tahun $529 \mathrm{M}$ oleh penguasa Romawi, Kaisar Justinian, menjadi peristiwa yang turut menandai perubahan penting dalam sejarah filsafat (Shand, 1993).

Pertama-tama, pusat momentum perkembangan filsafat ini sebenarnya tidak terjadi di daratan Yunani, melainkan di sekitar wilayah pesisir Ionia. Lokasinya di tepian Barat Laut Aegean yang sekarang dikenal sebagai Turki atau secara umum disebut Asia Minor. Daerah ini merupakan area perluasan kolonisasi Yunani sejak tahun 1000 SM pasca runtuhnya peradaban Mycenaean. Antara tahun 1580-1120 SM peradaban Mycenaean berkembang di daratan Yunani yang pada tingkatan tertentu dipengaruhi peradaban Minoan kuno di Kreta (3000-1000 SM) (Shand, 1993).

Berkembangnya aktivitas kefilsafatan ini tampaknya tidak bisa dilepaskan dari aspek sosial, ekonomi, dan juga politik yang berlangsung di lonia sekitar 700 SM. Pada masa itu, secara ekonomi lonia tumbuh pesat melalui kegiatan perdagangan yang ramai di seputar Mediteranian. Interaksi dengan pihak luar dari beragam latar budaya dan etnis mempengaruhi pertumbuhan budaya dan intelektual Ionia. Dari bangsa Scythian di Utara misalnya, mereka mengadopsi kepercayaan-kepercayaan samanistik yang mungkin telah memberi pengaruh pada Pythagoras. Dari bangsa Lydian dan Phrygian di Asia Minor, juga Kanaan dan Phoenician, Ionia beroleh sumbangan sangat penting berupa alfabet. Dari Mesir, matematika dan ilmu pengobatan diperkenalkan. Sementara dari imperium Babilonia yang jatuh di bawah kekuasaan Persia tahun 
538 SM Ionia menimba keilmuan matematika dan astronomi. Sementara itu dari pusat kekuasaan di daratan Yunani, negara-negara kota (city-states) semakin tumbuh kokoh dan menyebar ke lonia.

Negara-negara kota yang bercorak oligarki tersebut setidaknya mampu menciptakan suatu kondisi stabilitas menggantikan kekuasaan tidak stabil di bawah para despot absolut. Perubahan ini signifikan karena ia berkontribusi pada penguatan lingkungan yang kondusif bagi berkembangnya pemikiran filsafat dan sains. Dengan lingkungan yang semakin makmur dan relatif stabil serta adanya instrumen huruf alfabet menjadi peluang tumbuhnya spekulasi filosofis dan ilmiah (Shand, 1993).

\subsection{Filsafat dan Filsuf}

Prestasi perkembangan sains dan teknologi dewasa ini demikian jelas mendemonstrasikan keluasan cakrawala pengetahuan yang dicapai manusia. Namun seluas dan sedalam apapun pengetahuan itu diraih, tampaknya manusia harus tetap insyaf diri bahwa pengetahuannya tidak akan pernah utuh. Sebagaimana alam raya yang digambarkan oleh seorang penyair Persia sebagai buku kuno yang kehilangan halaman-halaman pertama dan terakhirnya, manusia tak akan pernah berhenti untuk mencari dan terus mencari. Seberapapun banyaknya halaman yang kemudian ia mampu temukan, halaman yang masih hilang seolah tetap saja tak pernah susut jumlahnya (Hamersma, 1990). Dari titik inilah filsafat sesungguhnya beranjak, yakni ketika manusia, entah dia laki-laki atau perempuan, menyadari betapa sedikit pengetahuan yang ia miliki. Sialnya (atau untungnya?), sebagaimana ilustrasi kisah di atas, bahkan ketika setumpuk pengetahuan sudah mampu manusia kuasai melalui proses panjang yang tidak mudah, ia masih juga berdiri di atas titik yang serupa. Betapa luas dan dalamnya samudera pengetahuan yang belum sempat dilihat apalagi disentuhnya.

Mereka itulah yang dikenal sebagai filsuf, seseorang yang secara serius berfikir mencari jawaban atas pertanyaan-pertanyaan yang muncul dari kompleksitas dan ketidakpastian hidup yang sanggup membuatnya heran (thaumasia) atau sangsi (skepsis). Mereka tidak menyebut dirinya sebagai manusia bijaksana, namun cukup sebagaimana Pythagoras (+581-507 SM) mendefinisikan dirinya, "pecinta kebijaksanaan" (Solomon \& Higgins, 2002).

Fakta sederhana yang membedakan mereka dari kebanyakan orang adalah kemauan kuatnya dalam menggunakan akal untuk berfikir secara merdeka. Mereka menguji dugaan-dugaan atau asumsi-asumsi yang kebanyakan orang seringkali hanya menerimanya begitu saja (taken for granted) tanpa berfikir atau menyoalnya. Menjunjung tinggi kebebasan berfikir ini merupakan salah satu daya tarik utama filsafat (philosophia) yang secara harfiah berarti mencintai (philein) kebijaksanaan (sophia). Dalam filsafat, tidak ada pernyataan atau pertanyaan yang tidak bisa dipertanyakan (Shand, 1993).

Filsafat bukanlah suatu kemewahan (a luxury) yang hanya bisa dilakukan oleh segelintir orang terpilih atau terdidik. Pada dasarnya, filsafat ini merupakan sesuatu yang lazim dapat dilakukan oleh siapapun yang 
mampu dan memiliki kemauan untuk menggunakan akalnya untuk berfikir tentang pengetahuan atau kepercayaan. Jadi, siapapun yang berfikiran terbuka dan secara kritis tertarik untuk terlibat menguji ide-ide daripada sekedar menerimanya secara buta pada saat yang sama telah melakukan apa yang disebut sebagai filsafat.

Filsafat dengan demikian mencakup upaya berfikir untuk menjelaskan ide-ide yang telah ada, menciptakan ide-ide baru yang imajinatif, dan juga menilai secara kritis kekuatan argumen yang diajukan untuk mendukung suatu pandangan tertentu yang diklaim sebagai benar. Pada konteks ini, akan dapat dijumpai bahwa ternyata tematema yang menjadi fokus perhatian para filsuf pada masa lampau ternyata masih tetap relevan dan aktual dikaji para pemikir kontemporer. Filsafat pada gilirannya dapat menjadi jembatan yang mampu mempertemukan para pemikir dalam suatu diskusi untuk mengupayakan pembuktian suatu kebenaran meskipun berasal dari periode historis yang berbeda (Shand, 1993).

\subsection{Tugas Filsafat}

Setidaknya ada tiga sudut pandang mengenai hal ini. Pertama, memandang filsafat sebagai penggunaan pemikiran logis untuk memecahkan masalah-masalah yang sukar, melalui penjernihan konsep-konsep kita. Ini merupakan ciri khas aliran "filsafat analitik", cenderung menganggap filsuf sebagai sejenis profesi ilmiah yang istimewa; mereka menolak terang-terangan gagasan bahwa filsafat itu berkaitan erat dengan kehidupan kita sehari-hari.

Kedua, memandang filsafat sebagai jalan hidup, sehingga tugas filsafat berkisar pada pemahaman hakikat dan tujuan keberadaan manusia beserta segala kerumitannya. Ini menjadi ciri khas aliran "eksistensialisme", cenderung menganggap filsafat sebagai disiplin-studi yang meliputi hampir segala hal yang dapat membantu kita menjalani hidup dengan lebih benar atau lebih "otentik.

Ketiga, mengakui bahwa kedua pendapat tadi diperlukan untuk menggagas tugas filosofik dengan tepat. Meyakini bahwa tujuan penjernihan konsep-konsep mengarah ke jalan hidup tertentu, dan bahwa penjelasan jalan hidup ini harus diungkap dengan gamblang dan jangan sampai terjerembab ke jurang kegelapan. Filsafat yang tidak ditatap sebagai jalan hidup lebih menyerupai ilmu yang bersifat teknis, sedangkan filsafat yang tidak menghajatkan upaya keras untuk menjernihkan konsep-konsep tampaknya lebih menyerupai agama yang bersifat mistis. Padahal, filsafat, bukanlah ilmu dan juga bukan agama, melainkan disiplin unik yang tegak di atas tapal batas antara keduanya.

\subsection{Manifestasi Filsafat}

Kita bisa memahami filsafat dalam dua bentuk. Pertama, filsafat sebagai proses (philosophy as process) yakni sebagai aktivitas berfilsafat (the activity of philosophizing). Tercakup di dalamnya adalah aspek-aspek: (a) analisis (the analytic), yakni berkaitan dengan aktivitas identifikasi dan pengujian asumsi-asumsi dan kriteria-kriteria yang memandu perilaku; (b) evaluasi (the evaluative), berkaitan dengan aktivitas kritik dan penilaian tindakan; (c) spekulasi (the speculative), berhubungan dengan pelahiran nalar baru dari nalar yang 
ada sebelumnya; (d) integrasi (the integrative), yakni konstruksi untuk meletakkan bersama atau mempertautkan kriteria-kriteria atau pengetahuan atau tindakan yang sebelumnya terpisah menjadi utuh.

Kedua, filsafat sebagai produk (philosophy as product) yakni produk dari aktivitas berfilsafat. Itu tidak lain adalah pemahaman (understanding), yakni klarifikasi kata, ide, konsep, dan pengalaman yang semula membingungkan atau kabur sehingga bisa menjadi jernih dan dapat dimanfaatkan untuk pencarian pengetahuan lebih lanjut.

\section{RUANG LINGKUP FILSAFAT}

Filsafat mengkaji apa yang ada dan yang mungkin ada. Secara umum, kajian tersebut mencakup tiga persoalan umum: Metafisika/Ontologi, Aksiologi, dan Epistemologi.

\subsection{Metafisika (Metaphysics)}

Istilah lebih generik adalah "ontology" yang berkenaan dengan hakikat realitas (what is), sedangkan metafisika berkenaan dengan hakikat eksistensi (what it means "to be"). Pada konteks ini keduanya dipakai saling menggantikan (interchangeably). Metafisika bisa diartikan sebagai the theory of reality. Suatu upaya filosofis untuk memahami karakteristik mendasar atau esensial dari alam semesta dalam suatu simpul yang sederhana namun serba mencakup. Secara sederhana, metafisikawan berusaha menjelaskan rangkuman dan intisari dari "apa" (of what is), "apa yg ada" (of what exists), dan "apa yg sejati ada" (of what is ultimately real).

Yang beraliran kuantitatif (as the sum of reality), metafisika mereka terpetakan dalam: (1) Monisme, (2) Dualisme, dan (3) Pluralisme. Yg beraliran kualitatif (as the substance of reality): (1) Idealisme, memandang hakikat realitas bersifat mental/spiritual; (2) Realisme, melihat hakikat realitas bersifat material/fisis. (3) Thomisme, mengkombinasikan 2 corak monisme tersebut. (4) Pragmatisme, menolak kuantifikasi atau kualifikasikan realitas. Mengatakan, realitas senantiasa berada pada keadaan berubah dan mencipta secara konstan sekalipun secara literal bisa dinyatakan ada ketidakterbatasan filosofis baik jenis maupun jumlahnya.

\subsection{Aksiologi (Axiology)}

Istilah yang lebih umum dipakai adalah etika (ethics) atau moral (morals). Tetapi dewasa ini, istilah axios (nilai) dan logos (teori) lebih akrab dipakai dalam dialog filosofis. Jadi, aksiologi bisa disebut sebagai the theory of value atau teori nilai. Bagian dari filsafat yang menaruh perhatian tentang baik dan buruk (good and bad), benar dan salah (right and wrong), serta tentang cara dan tujuan (means and ends). Aksiologi mencoba merumuskan suatu teori yang konsisten untuk perilaku etis. la bertanya seperti apa itu baik (what is good?).

Tatkala yang baik teridentifikasi, maka memungkinkan seseorang untuk berbicara tentang moralitas, yakni memakai kata-kata atau konsep-konsep semacam "seharusnya" atau "sepatutnya" (ought / should). 
Demikianlah aksiologi terdiri dari analisis tentang kepercayaan, keputusan, dan konsep-konsep moral dalam rangka menciptakan atau menemukan suatu teori nilai.

Terdapat dua kategori dasar aksiologis; (1) objectivism dan (2) subjectivism. Keduanya beranjak dari pertanyaan yang sama: apakah nilai itu bersifat bergantung atau tidak bergantung pada manusia (dependent upon or independent of mankind)? Dari sini muncul 4 pendekatan etika, 2 obyektivis dan 2 berikutnya subyektivis. Pertama, teori nilai intuitif (the initiative theory of value). Berpendapat bahwa sukar jika tidak bisa dikatakan mustahil untuk mendefinisikan suatu perangkat nilai yang bersifat ultim atau absolut. Kedua, teori nilai rasional (the rational theory of value). Menurutnya, janganlah percaya pada nilai yang bersifat obyektif dan murni independen dari manusia. Nilai tersebut ditemukan sebagai hasil dari penalaran manusia dan pewahyuan supranatural. Ketiga, teori nilai alamiah (the naturalistik theory of value). Baginya, nilai diciptakan manusia bersama dengan kebutuhan-kebutuhan dan hasrat-hasrat yang dialaminya. Nilai adalah produk biososial, artefak manusia, yang diciptakan, dipakai, diuji oleh individu dan masyarakat untuk melayani tujuan membimbing perilaku manusia. Keempat, teori nilai emotif (the emotive theory of value). Di sini, konsep moral dan etika bukanlah keputusan faktual tetapi hanya merupakan ekspresi emosi-emosi atau tingkah laku (attitude).

\subsection{Epistemologi (Epistemology)}

Disebut the theory of knowledge atau teori pengetahuan. la berusaha mengidentifikasi dasar dan hakikat kebenaran dan pengetahuan, dan mungkin inilah bagian paling penting dari filsafat untuk para pendidik. Pertanyaan khas epistemologi adalah bagaimana kamu mengetahui (how do you know?).

Pertanyaan ini tidak hanya menanyakan tentang apa (what) yang kita tahu (the products) tetapi juga tentang bagaimana (how) kita sampai mengetahuinya (the process). Para epistemolog adalah para pencari yang sangat ulet. Mereka ingin mengetahui apa yang diketahui (what is known), kapan itu diketahui (when is it known), siapa yang tahu atau dapat mengetahuinya (who knows or can know), dan yang terpenting, bagaimana kita tahu (how we know). Mereka adalah para pengawas dari keluasan ranah kognitif manusia.

Pertanyaan-pertanyaan tersebut didahului dengan pertanyaan dapatkah kita mengetahui (can we know?). Di sini terdapat 3 (tiga) posisi epistemologis: Pertama, dogmatisme. Aliran ini menjawab: ya, tentu saja kita dapat dan benar-benar mengetahui (we can and do know) - selanjutnya bahkan kita yakin (we are certain). Kedua, skeptisisme. Aliran ini menjawab: tidak, kita tidak benar-benar tahu dan tidak juga dapat mengetahui. Ketiga, fallibilisme. Aliran ini menjawab bahwa kita dapat mengetahui sesuatu, tetapi kita tidak akan pernah mempunyai pengetahuan pasti sebagaimana pandangan kaum dogmatis. Mereka ini hanya mengatakan mungkin (possible), bukan pasti (certain).

\section{RELASI FILSAFAT DENGAN AGAMA, SAINS, DAN SENI}

4.1 Filsafat, Agama, Sains, dan Seni 
Filsafat bermula ketika manusia berusaha memahami dunianya bukan melalui agama atau otoritas lainnya, tetapi dengan menggunakan rasio. Argumen filosofis mendapatkan dukungan dari dalam dirinya sendiri, yakni rasio. Argumennya menuntut persetujuan rasional manusia, bukan iman ataupun ketaatan. Filsafat mengandalkan rasio sejauh-jauhnya. Simpulan filosofis menuntut alasan yang benar-benar baik untuk dapat kita percayai. Tidak boleh pasrah menerima berdasar spekulasi, iman, atau karena intuisi mengatakannya demikian. Berpegang teguh pada rasio inilah kekhasan filsafat yang membedakannya dari agama, seni, dan sains.

Dalam kaitannya dengan agama, filsafat ada kalanya mendefinisikan agama dan ada kalanya yang terjadi adalah sebaliknya. Filsafat mendefinisikan agama dapat diambil contonya seperti yang terjadi dalam kasus Konfusius dan Buddhisme. Adapun untuk agama yang mendefinisikan filsafat banyak dijumpai dalam tradisi pemikiran kefilsafatan yang berkembang dalam kultur keagamaan samawi seperti misalnya filsafat Islam. Tetapi yang jelas, filsafat dapat berperan di dalam atau di luar batas-batas agama, sebaliknya adalah keliru bila disimpulkan bahwa agama berada di luar batas-batas pembahasan filsafat (Santosa, 2015).

Meski berbeda, filsafat, sains, dan seni tidak bertentangan. Ketiganya berupaya mencapai pemahaman yang mendalam tentang dunia ini. Sama-sama menghadapi misteri eksistensi dunia ini dan kita sebagai manusia. Kesemuanya menjelajah pengetahuan dan pengalaman manusia. Menyingkap yang tersembunyi, menata temuan-temuan, dan membaginya kepada publik. Mereka juga saling memperkaya. Manusia yang benar-benar utuh secara alami akan tertarik kepada kesemuanya. "Hampir selalu praktisi terbaik dlm setiap bidang menaruh minat terhadap filsafat bidangnya".

\subsection{Bunga Filsafat}

Filsafat menyadarkan kita untuk insyaf diri sebagai manusia. Filsafat mendidik kita untuk menghargai hidup dan sesama. Filsafat mendidik kita untuk selalu waspada dan rendah hati. Filsafat mendidik kita untuk setia pada kebenaran. Filsafat mendidik kita untuk bersikap dan bertindak bijaksana. Filsafat mendorong kita untuk aktif, positif, dan peduli. Filsafat mendorong kita mencari dan menemukan "kepuasan", "kebermaknaan", dan "kebahagiaan" dalam hidup.

\section{RINGKASAN}

5.1 Filsafat sudah muncul berkali-kali di banyak tempat di belahan bumi ini. Filsafat (philosophia) secara harfiah berarti mencintai (philein) kebijaksanaan (sophia). Dalam filsafat, tidak ada pernyataan atau pertanyaan yang tidak bisa dipertanyakan. Filsafat sebenarnya bukanlah suatu kemewahan (a luxury) yang hanya bisa dilakukan oleh segelintir orang terpilih atau terdidik. Pada dasarnya, filsafat ini merupakan sesuatu yang lazim dapat dilakukan oleh siapapun yang mampu dan memiliki kemauan untuk menggunakan akalnya untuk berfikir tentang pengetahuan atau kepercayaan. Jadi, siapapun yang berfikiran terbuka dan secara kritis tertarik untuk terlibat 
menguji ide-ide daripada sekedar menerimanya secara buta pada saat yang sama telah melakukan apa yang disebut sebagai filsafat.

Filsuf dengan demikian adalah seseorang yang secara serius berfikir mencari jawaban atas pertanyaan-pertanyaan yang muncul dari kompleksitas dan ketidakpastian hidup yang telah sanggup membuatnya ingin tahu. Setidaknya, terdapat tiga sudut pandang mengenai tugas filsafat: (1) untuk menjernihkan konsep-konsep; (2) sebagai jalan hidup; dan (3) memandang dua tugas sebelumnya sama-sama diperlukan untuk menggagas tugas filosofis dengan tepat.

5.2 Filsafat mengkaji apa yang ada dan yang mungkin ada. Kajian tersebut mencakup tiga persoalan umum, yaitu ontologi atau metafisika, aksiologi, dan epistemologl. Metafisika bisa diartikan sebagai the theory of reality, atau teori tentang realitas. Aksiologi bisa disebut sebagai the theory of value atau teori nilai. Sedangkan epistemologi menyoal tentang the theory of knowledge atau teori pengetahuan.

5.3 Meski dapat dibedakan, filsafat, agama, sains, dan seni kesemuanya menjelaskan kepada manusia tentang realitas. Kesemuanya menggoda manusia untuk mencapai pemahaman yang memadai tentang diri dan dunia yang mengitarinya.

\section{LATIHAN SOAL}

1. Jelaskan bagaimana filsafat lahir!

2. Jelaskan pengertian filsafat!

3. Siapakah yang dimaksud sebagai filsuf itu?

4. Siapa saja yang bisa berfilsafat?

5. Jelaskan tugas-tugas filsafat!

6. Jelaskan ruang lingkup kajian filsafat!

7. Jelaskan tiga persoalan umum yang menjadi kajian filsafat!

8. Jelaskan relasi yang menghubungkan sekaligus membedakan antara filsafat, agama, sains, dan seni!

9. Jelaskan perlunya mempelajari filsafat! 


\section{BAB II}

\section{FILSAFAT ILMU DAN PENGETAHUAN MANUSIA}

\section{PENDAHULUAN}

1.1 Deskripsi Singkat

Bab ini mendiskusikan tentang pengertian filsafat ilmu, pengetahuan, klasifikasi pengetahuan, dan permasalahan pengetahuan manusia secara umum.

1.2 Relevansi

Melalui bab ini mahasiswa diharapkan memiliki pemahaman tentang pengertian filsafat ilmu berikut ragam konsepsi dasar pengetahuan dan problematika pengetahuan manusia.

\subsection{Kompetensi Dasar}

a. Mahasiswa mampu menjelaskan pengertian filsafat ilmu.

b. Mahasiswa mampu menjelaskan konsep-konsep dasar yang berkaitan dengan bangun pengetahuan manusia.

1.4 Indikator

1. Mahasiswa dapat menjelaskan pengertian filsafat ilmu.

2. Mahasiswa dapat menyebutkan dan menjelaskan konsep-konsep dasar yang berkaitan dengan bangun

pengetahuan manusia.

\section{FILSAFAT ILMU DAN PENGETAHUAN MANUSIA}

\subsection{Filsafat IImu}

Dari ruang lingkup serta persoalan yang dikaji filsafat kita kenal ontologi, aksiologi, dan epistemologi. Filsafat ilmu akrab diidentikkan dengan epistemologi, yakni kajian sistematis tentang pengetahuan manusia dan justifikasi atau argumentasi atas kebenarannya, the theory of knowledge and justification (Audi, 2003). Sifatnya evaluatif, normatif, serta kritis terhadap nilai kognitif pengalaman manusia dalam interaksinya dengan diri dan lingkungannya.

Keingintahuan merupakan salah satu karakteristik manusia yang berakal. Sepanjang hidup kita, banyak hal yang ingin kita ketahui. Mulai dari hal-hal kongkrit dalam hidup keseharian kita hingga hal-hal yang bersifat abstrak. Ketika baru mengenal sebuah aplikasi di gawai, blueetooth misalnya, pertanyaan tentang apa fungsinya dan bagaimana mengoperasikannya serta merta akan muncul di benak kita. Ketika seorang remaja mulai tertarik kepada lawan jenisnya, ia mungkin akan bertanya tentang apa artinya cinta dan 
kehadiran orang lain dalam hidupnya. Sebagaimana halnya tak jarang kita juga bertanya tentang eksistensi kita sendiri. Tentang mengapa kita ada di dunia ini dan apa hubungannya dengan makhluk-makhluk lainnya yang ada di sekitar kita. Atau ketika mendengar ada orang yang tidak percaya adanya Tuhan, bisa jadi kita pun akan tertarik untuk mencoba memahami lebih mendalam tentang keberadaan-Nya. Pertanyaan-pertanyaan semacam itu merupakan ekspresi dari keingintahuan manusia tentang sesuatu.

Keingintahuan inilah yang lantas mendorong manusia untuk mencari tahu. la menjumpai hal-hal yang menarik atau memaksa dirinya untuk mengetahuinya karena ternyata hal-hal tersebut masih asing baginya atau belum diketahuinya secara memadai. la berusaha mencari jawaban untuk memuaskan rasa keingintahuannya yang terekspresi melalui pertanyaan-pertanyaan tentang hal-hal yang asing atau belum diketahuinya itu. Jadi, keingintahuan manusia ini sebenarnya secara sederhana dapat dipahami sebagai suatu kondisi dimana manusia tersadarkan atas kekurangan dirinya. Bahwa ternyata masih ada hal-hal yang belum diketahui atau dipahaminya. Dan karena ketidaktahuan atau ketidakpahamannya itu, tidak mustahil ia mendapati kesulitan ketika harus menjelaskan atau berinteraksi dengannya.

Dalam kondisi semacam ini, kekeliruan sangat mungkin terjadi. Seperti seorang anak yang diberi hadiah sepaket kartu AnimalKaiser yang belum pernah dikenalnya, ia akan memahami kartu-kartu tersebut tak berbeda dengan kartu-kartu mainan biasanya. Di mana ia biasa memainkan kartu-kartu bergambar itu bersama teman-temannya untuk saling beradu dengan cara melemparnya ke udara. Padahal kalau saja ia mengetahui, lebih dari cara tradisional bermain kartu semacam itu, kartu AnimalKaiser bisa membantunya memainkan seperangkat program permainan digital melalui sebuah mesin. Tiap jenis kartu seperti Animal Card, Strong Card, dan Miracle Card masing-masing memiliki fungsinya yang spesifik dan berbeda dengan lainnya.

Jadi, secara tabiat manusia bersifat ingin tahu. Keingintahuannya tersebut biasanya dimunculkan dalam bentuk pertanyaan. Jawaban bagaimana yang dikehendaki untuk dapat memuaskan keingintahuannya tersebut, tentu adalah jawaban yang benar bukan yang keliru. Pada konteks inilah perlu dipahami beberapa konsep dasar dalam bidang kefilsafatan yang berhubungan erat dengan bangun pengetahuan manusia.

\subsection{Keyakinan, Kepastian, Kesungguhan}

Keyakinan adalah sikap mental subyek yang tahu sesuatu bhw demikianlah halnya sesuatu itu benar adanya, pendapat lain tak mungkin. Keyakinan sifatnya selalu subyektif. Kemungkinan keliru selalu ada, sehingga revisi atau pembetulan keyakinan juga senantiasa terbuka. Dengan keyakinannya itu, subyek bisa merasa pasti akan pengetahuannya. Meski kepastian tidak semua sama pastinya. Kesungguhan atau realitas, yaitu adanya sesuatu hal disadari dan dikenali subyek demikian itu. Macamnya ada dua: yang kongkrit (baik fisis maupun psikis) dan abstrak.

\subsection{Keyakinan dan Kepercayaan}


Keyakinan tidak selalu mengandung kebenaran (logis). Keyakinan bisa muncul karena penyelidikan sendiri dan bisa juga karena pemberitahuan orang lain. Pengetahuan yang diperoleh atas dasar percaya, yaitu menerima kebenaran demi kewibawaan, disebut kepercayaan. Kepastian karena percaya tidak perlu kurang pastinya dari kepastian karena diperoleh sendiri.

\subsection{Kepastian, Dugaan, Kesangsian}

Ada putusan yang didasari bukti-bukti sehingga subyek merasa yakin bahwa selainnya tak mungkin benar, ini kepastian. Ada putusan yang didasari beberapa bukti tetapi tanpa keyakinan bahwa kebalikannya tidak mungkin benar, ini dugaan. Ketika seseorang merasa tahu sedikit tentang sesuatu, tetapi tidak cukup alasan tentang kebenarannya, atau ada juga alasan bahwa kebalikannya mungkin benar, ia dihinggapi kesangsian.

Kesangsian secara konseptual adakalanya dibedakan dari keraguan. Jika ragu-ragu mengandung arti tidak berani mengadakan putusan untuk bertindak (sifatnya melemahkan), maka sangsi merupakan sikap mental terhadap suatu pengetahuan yang belum dapat diyakini kebenarannya (sifatnya mendorong penyelidikan).

\subsection{Jenis Pengetahuan}

Kita mengenal apa yang dinamakan sebagai pengetahuan khusus (partikular), berlaku bagi yang satu/tertentu saja. Misal, "Singa Raja itu jinak." Ada juga yang disebut pengetahuan umum (universal), berlaku bagi seluruh macam dan masing-masing dalam macamnya. Contoh, "Singa adalah karnivora." Manusia mengetahui yang umum melalui yang khusus.

\subsection{Kebenaran dan Kekeliruan}

Kebenaran adalah persesuaian antara pengetahuan dan obyeknya. Sukar mencapai seluruh kebenaran karena suatu obyek memiliki banyak aspek. Tidak mengetahui salah satu aspek dari obyek "bukanlah kekeliruan", tetapi "belum lengkapnya pengetahuan". Kekeliruan adalah ketidaksesuaian antara pengetahuan dan obyeknya.

\subsection{Jenis Kebenaran}

Kebenaran logis (obyektif) adalah persesuaian antara pengetahuan dan obyeknya. Misal, "Itu air". Kebenaran ontologis merupakan persesuaian obyek dalam halnya sendiri semisal "air (sebagai air)". Dalam ilmu yg diutamakan adalah kebenaran logis.

2.8 Tingkatan Pengetahuan 
Ada yang kita kenal sebagai pengetahuan biasa, yakni pengetahuan atas sesuatu yang berguna dalam hidup sehari-hari tanpa detail seluk-beluk tentang pengetahuan itu sendiri. Misal, "Air mendidih jika dipanasi". "Baju basah jika dijemur di terik matahari akan menjadi kering". Ilmu adalah pengetahuan yang bersifat detail/mendalam tentang sesuatu. Contoh, "Air membeku $p d$ suhu $0^{\circ} \mathrm{C}^{\prime}$. "Air mendidih pd suhu $100^{\circ} \mathrm{C}$ ". Tujuan utama IImu adalah mencapai "kebenaran" (ilmu). Ini tidak mudah karena harus ada pembuktian secara ilmiah. Dibutuhkan kesungguhan, kecerdasan, kejujuran, dan keberanian. Dan jika mempelajari fakta-fakta ilmiah ini membutuhkan hal tersebut, maka menyusun gambaran utuh dari fakta-fakta tentu membutuhkan komitmen yang lebih besar lagi.

Sifat ilmu di antaranya berobyek, bermetode, universal, bersistem. Dalam praktiknya, ilmu (pengetahuan ilmiah) tampak membatasi diri pada pengalaman (pembuktian empiris). Adapun upaya yg mencoba menemukan penjelasan sedalam-salamnya (seumum-umumnya) dan utuh atas segala sesuatu yang ada atau mungkin ada (tidak membatasi diri pada pembuktian empiris) bisa dinamai Filsafat. Namun patut diingat bahwa apa yang dalam teori jelas garis pemisahnya, dalam praktek tidak selalu menjadi terang.

\section{RINGKASAN}

Secara tabiat manusia bersifat ingin tahu. Untuk memuaskan keingintahuannya tentang sesuatu, manusia menginginkan jawaban atau penjelasan yang benar mengenai hal itu. Di sinilah filsafat ilmu perlu dipelajari. Disiplin keilmuan yang juga akrab diidentikkan dengan epistemologi ini mengkaji secara sistematis pengetahuan manusia dan justifikasi atau argumentasi atas kebenarannya. Kajian ini akan mengantarkan pengkajinya untuk memahami berbagai konsep dasar seperti keyakinan, kepercayaan, kepastian, kesungguhan, dugaan, kesangsian, jenis-jenis pengetahuan, kebenaran dan kekeliruan, jenis-jenis kebenaran, serta tingkatan pengetahuan.

\section{LATIHAN SOAL}

1. Apa yang dikaji dalam filsafat ilmu?

2. Jelaskan beberapa konsep berikut ini: keyakinan, kepercayaan, kepastian, kesungguhan, dugaan, kesangsian, kebenaran, dan kekeliruan!

3. Sebutkan dan jelaskan jenis-jenis pengetahuan!

4. Sebutkan dan jelaskan jenis-jenis kebenaran! 


\section{BAB III}

\section{KARAKTERISTIK ILMU}

\section{PENDAHULUAN}

\subsection{Deskripsi Singkat}

Bab ini mendiskusikan tentang karakteristik ilmu atau lebih spesifik yaitu pengetahuan ilmiah atau yang juga akrab diistilahkan dengan sains (science).

\subsection{Relevansi}

Melalui bab ini mahasiswa diharapkan memiliki pemahaman dan wawasan mengenai kekhasan atau karakter distingtif yang dimiliki oleh ilmu sehingga terbedakan dari jenis pengetahuan lainnya.

\subsection{Kompetensi Dasar}
a. Mahasiswa mampu menjelaskan pengertian ilmu.
b. Mahasiswa menjelaskan karakteristik ilmu.

1.4 Indikator
a. Mahasiswa dapat menjelaskan pengertian ilmu.
b. Mahasiswa dapat menjelaskan karakteristik ilmu.

\section{PENGERTIAN ILMU}

Apakah yang dimaksud dengan ilmu? Sebelum menjelaskan jawaban atas pertanyaan ini, maka dalam buku ini, perlu didudukkan terlebih dahulu bagaimana terma ilmu itu dipakai dalam buku ini. Ilmu di sini disamakan dengan pengetahuan ilmiah (scientific knowledge). Ilmu juga bisa diistilahkan lain sebagai sains (science). Dan mengingat bahwa istilah sains di Indonesia sering disempitkan pengertiannya hanya sebatas ilmu pengetahuan alam atau natural sciences, maka di sini oleh mahasiswa atau pembaca perlu dipahami bahwa sains yang dimaksudkan dalam buku ini mencakup seluruh bangun pengetahuan ilmiah termasuk di dalamnya ilmu-ilmu sosial (social sciences) dan humaniora (humanities).

Apa itu sains? Banyak ahli yang menyatakan bahwa sains merupakan jenis pengetahuan yang dapat dibedakan dari jenis pengetahuan lainnya dari metode yang dipergunakan para ilmuwan dalam penyelidikan ilmiahnya. Jadi sains mengaplikasikan metode-metode yang tidak dipakai disiplin-disiplin lain yang tidak ilmiah (Okasha, 2002). Secara sederhana sains atau pengetahuan ilmiah adalah pengetahuan yang diperoleh dan dapat dipertanggung-jawabkan keilmiahannya secara metodis. Pemerolehan ilmu secara metodis ini sekaligus menunjukkan bahwa ilmu lahir sebagai hasil dari suatu proses penalaran (reasoning) atau proses 
inferensi (inference). Terdapat beberapa model penalaran ilmiah (scientific reasoning) yang kita kenal, yaitu induksi, deduksi, dan abduksi. Hal ini akan dibahas lebih lanjut dalam bab lainnya di buku ini.

\section{KARAKTERISTIK ILMU}

Salah satu jendela terbuka yang memungkinkan kita untuk melihat dan memahami kekhasan dari ilmu adalah rumusan etos sains yang dikemukakan oleh Robert Merton. Dijelaskan oleh Huff (2003), pemikiran Merton ini mengajukan setidaknya 4 (empat) norma yang jadi elemen dasar etos pengetahuan ilmiah.

\subsection{Universalisme (Universalism)}

Norma ini menunjukkan dua keharusan: pertama, bahwa klaim pengetahuan harus dinilai secara tidak pribadi (impersonally) sesuai dengan kriteria standar dan tanpa memperhatikan karakteristik pribadi peneliti; dan kedua, bahwa semua orang, terlepas dari ikatan etnis atau kekerabatan, atau pengetahuan agama, harus diterima secara bebas ke dalam semesta wacana ilmiah.

\subsection{Komunalisme (Communalism)}

Menurut keharusan ini, temuan penelitian adalah milik masyarakat luas dan tidak boleh dirahasiakan atau digunakan semata-mata hanya oleh peneliti. Seseorang diperintahkan untuk membuat hasil temuan tersebut tersedia melalui publikasi segera setelah peringatan normal tentang kesalahan dan ketepatan diambil.

\subsection{Tanpa Pamrih (Disinterestedness)}

Menurut norma ini, ilmuwan diharapkan menampilkan upaya perburuan untuk menemukan kebenaran ilmiah yang bersifat tidak memihak melalui sarana yang tersedia untuk umum dan guna melupakan segala bentuk motif keuntungan dan kebesaran pribadi.

\subsection{Skeptisisme Tertata (Organized Skepticism)}

Imperatif kelembagaan ini memerintahkan "penghentian sementara penilaian dan pengawasan kepercayaan yang terpisah dalam hal kriteria empiris dan logis," dan penerapan sikap ini terhadap semua klaim pengetahuan, bahkan yang dikeluarkan dari lembaga lain yang dianggap baik. Orang mungkin berkomentar bahwa norma ini sangat fluktuatif dan bahwa masyarakat tradisional (atau yang berkembang belakangan) sangat peka terhadap kritik dan pertanyaan yang diarahkan pada nilai-nilai sentral dan sakral mereka.

\section{RINGKASAN}

IImu, pengetahuan ilmiah, atau sains adalah pengetahuan yang diperoleh dan dapat dipertanggung-jawabkan keilmiahannya secara metodis. Pemerolehan ilmu secara metodis ini sekaligus menunjukkan bahwa ilmu lahir sebagai hasil dari suatu proses penalaran atau proses inferensi yang bersifat ilmiah (scientific reasoning or scientific inference). Ilmu merupakan pencapaian intelektual manusia yang 
diraih melalui upaya yang karakteristiknya mengindahkan norma-norma tertentu di antaranya: universalisme, komunalisme, tanpa pamrih, dan skeptisisme tertata.

\section{LATIHAN SOAL}

1. Jelaskan apa yang dimaksud dengan ilmu, pengetahuan ilmiah, atau sains itu!

2. Sebutkan dan jelaskan karakter dari ilmu yang membedakannya dari jenis pengetahuan lainnya! 


\section{BAB IV}

\section{ILMU DALAM PERSPEKTIF ISLAM}

\section{PENDAHULUAN}

\subsection{Deskripsi Singkat}

Bab ini mendiskusikan tentang bagaimana ilmu ditinjau dari kacamata Islam.

\subsection{Relevansi}

Melalui bab ini mahasiswa diharapkan memiliki pemahaman dan wawasan mengenai ilmu secara Rabbani atau Qur'ani.

\subsection{Kompetensi Dasar}

Mahasiswa mampu menjelaskan kedudukan ilmu dalam perspektif Islam.

\subsection{Indikator}

a. Mahasiswa dapat menjelaskan kedudukan ilmu dalam perspektif Islam.

b. Mahasiswa dapat menjelaskan keutamaan ilmu dalam perspektif Islam.

\section{ILMU}

Istilah yang digunakan dalam khazanah ilmu pengetahuan Islam untuk pengetahuan dalam bahasa Arab adalah 'ilm, yang memiliki konotasi yang jauh lebih luas daripada sinonimnya dalam bahasa Inggris dan bahasa Barat lainnya. Pengetahuan di dunia Barat berarti informasi tentang sesuatu, sedangkan 'ilm adalah istilah yang mencakup semua yang mencakup teori, tindakan, dan pendidikan. Dan ini memberi bentuk yang khas bagi peradaban Muslim dan Islam. Tidak ada satupun dalam aspek kehidupan intelektual Muslim yang tak tersentuh oleh keluasan pemaknaan pengetahuan. Dalam al-Qur'an sendiri tidak kurang dari 140 kali kata 'alim disebut, sedangkan al-'ilm sebanyak 27 kali. Sedangkan total ayat yang menggunakan kata derivasi dari 'ilm tidak kurang dari 704 jumlahnya. Tak kurang jumlahnya pula al-Qur'an menyebut hal-hal terkait dengan pengetahuan seperti buku, pena, tinta, dan lain-lainnya. Kata qalam ada 2 tempat, al-kitab di 230 ayat, di antaranya termasuk al-kitab untuk menyebut al-Qur'an sebanyak 81 ayat. Terkait penulisan tak kurang dari 319 ayat. Bahkan wahyu pertama yang turun di awali dengan kata iqra', bacalah! Kesemuanya itu berimplikasi pada pengertian bahwa 'ilm merupakan kewajiban atas tiap Muslim yang mencakup ragam disiplin keilmuan. Ringkasnya, 'ilm tak semata berarti pemerolehan pengetahuan semata, tetapi juga memangku aspek-aspek sosio-politik and moral. Jadi pengetahuan tak sekedar informasi, tapi mengkombinasikan pengetahuan, wawasan, dan tindakan sosial sebagai bahan dasarnya. 
Dalam tradisi Ibnu Rusyd, sebagaimana dipaparkan oleh Nidhal Guessoum (2011), bahwa filsafat itu sejatinya adalah studi tentang apa yang ada serta refleksi atasnya. Semakin seseorang memahami dengan baik serta mendalam mengenai suatu hal, ambilnya suatu karya seni, maka semakin baik pula pengenalan dan pemahaman dia tidak saja atas kualitas dari karya seni yang dikaji, tetapi juga atas sang seniman sebagai orang yang menghasilkan karya. Pada konteks ini, maka studi filsafat dan logika dalam kacamata Islam sebagaimana Ibnu Rusyd memandangnya dari titik tolak kajian hukum, bisa jadi boleh, haram atau wajib, sunnah atau makruh.

Jika nalar tersebut di atas kita pakai, maka sesungguhnya, pemanfaatan akal budi kita, nalar kita, atas alam semesta seisinya tidak lain dan tidak bukan adalah dalam rangka semakin mendekatkan kita untuk lebih mengenal dan memahami siapa sesuangguhnya dan sejatinya Sang Pencipta alam raya seisinya ini. Semakin baik pengenalan dan pemahaman kita atas ciptaan atau makhluk, maka akan seharusnya akan semakin baik pula pengenalan dan pemahaman kita atas Pencipta dan Khaliq.

Al-Qur'an menurut Ghaleb Hasan telah mendedahkan prinsip-prinsip filosofis penting tentang sains, di antaranya:
a. Kesatuan (unity);
b. Generalisasi (generalization);
c. Prediksi (prediction).

Untuk mendukung pemahamannya ini dikutipkan ayat 43 dari surah ke-35 (al-Faatir): "Maka sekali-kali kamu tidak akan mendapat penggantian bagi sunnah Allah, dan sekali-kali tidak (pula) akan menemui penyimpangan bagi sunnah Allah itu." Sains sendiri bisa diartikan sebagai tindakan penafsiran atas ayat-ayat Allah. Adapun tujuan umum dari sains adalah:

a. Memuaskan hasrat kemanusiaan kita untuk memahami apa yang ada di sekitar kita.

b. Memperbaiki dunia, di mana manusia dihadirkan sebagai khalifah.

c. Mengidentifikasi Prinsip Pertama, yakni sebab dari alam semesta, atau dengan kata lain menggapai Tuhan.

\section{RINGKASAN}

IImu memiliki kedudukan yang sangat vital dalam Islam dan kehidupan seorang Muslim. Setiap Muslim berkewajiban mencari IImu untuk menopang pernyataan imannya. Namun pemaknaan ilmu dalam Islam tak sekedar informasi, ia mencakup pengetahuan, wawasan, dan tindakan sosial sebagai bahan dasarnya.

\section{LATIHAN SOAL}

Jelaskan kedudukan dan keutamaan ilmu dalam perspektif Islam! Berikan pula beberapa referensi normatifnya! 


\section{BAB V}

\section{DASAR-DASAR PENGETAHUAN MANUSIA}

\section{PENDAHULUAN}

1.1 Deskripsi Singkat

Bab ini mendiskusikan tentang dasar-dasar pengetahuan manusia, mencakup pengalaman, ingatan, kesaksian, minat dan rasa ingin tahu, pikiran dan penalaran, logika, bahasa, dan kebutuhan hidup manusia.

1.2 Relevansi

Melalui bab ini mahasiswa diharapkan memiliki pemahaman dan wawasan tentang konstruksi atau pilar-pilar penopang pengetahuan manusia.

\subsection{Kompetensi Dasar}

a. Mahasiswa mampu menyebutkan dasar-dasar pengetahuan manusia.

b. Mahasiswa mampu menjelaskan konstruksi atau pilar-pilar yang menopang pengetahuan manusia.

1.4 Indikator

1. Mahasiswa dapat menyebutkan pokok-pokok dasar pengetahuan manusia.

2. Mahasiswa dapat menjelaskan konstruksi atau pilar-pilar yang menopang pengetahuan manusia.

\section{DASAR-DASAR PENGETAHUAN}

Pengetahuan dapat dibangun karena adanya faktor-faktor yang memungkinkan hal tersebut dilakukan. Faktor-faktor tersebut meliputi pengalaman, ingatan, kesaksian, minat dan rasa ingin tahu, pikiran dan penalaran, logika, bahasa, dan kebutuhan hidup manusia.

\subsection{Pengalaman}

Keseluruhan peristiwa perjumpaan dan apa yang terjadi pada manusia dalam interaksinya dengan alam, diri sendiri, lingkungan sosial, dan keseluruhan kenyataan termasuk yang ilahi merupakan pengalaman. Ragamnya: primer (langsung; inderawi) dan sekunder (tdk Ingsung; reflektif; nir-inderawi). Ciri2nya: jamak/beragam; berhubungan dengan sesuatu di luar subyek; dan bertumbuh.

\subsection{Ingatan}

Yaitu gagasan/gambaran (yang telah dikenali di waktu lampau) dalam pikiran atau yang hadir dalam kesadaran aktual/sekarang. Secara teoritis/praktis, pengethuan adalah ingatan; tanpanya 
pengetahuan menjadi mustahil. Saling mengandaikan dengan pengalaman inderawi. Ingatan tidak selalu benar, bisa memuat ketidaktepatan. Suatu ingatan dapat dipertanggungjawabkan dengan syarat antara lain: (1) kesaksian mengingat; (2) konsisten dan 'solutif'.

\subsection{Kesaksian}

Yaitu penegasan sesuatu sebagai benar oleh saksi kejadian/peristiwa yang diajukan kepada orang lain untuk dipercaya. Kebenarannya bersandar pada otoritas/kewenangan saksi yang didukung antara lain secara intrinsik dengan kompetensi yang bersangkutan. Kesaksian juga bisa keliru atau palsu seperti krn konspirasi. Tidak memberl kepastian mutlak.

\subsection{Minat / Rasa Ingin Tahu}

Kata Aristoteles, "Semua manusia ingin mengetahui". Menyadari ketidaktahuan dan dorongan keingintahuan penting dalam aktivitas berpengetahuan. Erat terkait dengan pengalaman kekaguman / keheranan. Biasanya dimulai dengan bertanya/menyelidik. Mengajukan pertanyaan yang tepat adalah langkah awal untuk memperoleh jawaban yang benar. Kegiatan mengetahui selalu memuat unsur penilaian; didorong minat pada sesuatu yang dianggap 'bernilai'.

\subsection{Pikiran / Penalaran}

Kegiatan pokok pikiran untuk mengetahui adalah penalaran, yakni proses bagaimana pikiran menarik simpulan dari hal-hal yang sebenarnya telah diketahui. Biasanya dilakukan seturut asas kelurusan berpikir / sesuai dengan hukum logika. Penalaran vital untuk pengembangan pengetahuan, adaptasi lingkungan, atau juga merubah linkungan sesuai kepentingan.

\subsection{Logika}

Hukum keruntutan kegiatan berpikir dalam menarik / melakukan simpulan adalah logika. Bentuknya bisa induksi; deduksi; dan abduksi (hipotetik). Hasil penalaran (simpulan) deduktif bisa dinyatakan sahih/valid; yakni niscaya benar jika premis-premisnya benar. Biasanya diungkapkan dalam bentuk silogisme. Simpulan induktif / abduktif tidak bisa dinyatakan sahih/valid; tapi bisa dinyatakan sebagai terjamin atau tidak, didasarkan pada bagaimana prosesnya dilakukan.

Silogisme bisa berbentuk silogisme kategoris, hipotesis, dan disjungtif. Silogisme kategoris adalah silogisme yang terdiri dari proposisi-proposisi kategoris (mayor - minor - konklusi). Macamnya ada yang positif atau negatif; juga ada yang universal atau partikular. Silogisme hipotesis terdiri dari proposisi bersyarat. Premis mayor-nya merupakan suatu implikasi berbntuk kalau/jk ... mk .... Macamnya ada dua, modus ponens ( $j k p \rightarrow q$; $p p ; m k q$ ) dan modus tollens ( $j k p \rightarrow q ; t p-p ; m k-$ q). Silogisme disjungtif mengimperasikan bahwa yang sahih hanya satu kemungkinan dan menyingkirkn lainnya (atau $p$, atau $q$, atau $r ; t t p-p$ dan $-q ; m k r$ ).

\subsection{Bahasa}


Pengetahuan manusia selalu diungkapkan dalam bentuk bahasa. Ini sangat terkait dengan pikiran dan kata. Bahasa penting sebagai sarana diskursus, atau pertukaran bagi diseminasi, perluasan dan pengembangan pengetahuan manusia. Bentuknya bisa lisan dan tulis.

\subsection{Kebutuhan Hidup Manusia}

Pengetahuan penting manusia dan kehidupannya. Karena secara mendasar, pengetahuan berfungsi untuk memenuhi kebutuhan hidup manusia. Selain penting untuk pengembangan ilmu pengetahuan itu sendiri, pengetahuan akan sangat membantu member solusi bagi manusia dalam beradaptasi dengan lingkungan, atau juga merubah linkungan agar sesuai dengan kepentingannya.

\section{RINGKASAN}

Terdapat banyak faktor yang mempengaruhi atau memungkinkan pengetahuan manusia dapat terbangun. Faktor-faktor tersebut dapat disebutkan sebagai berikut: pengalaman, ingatan, kesaksian, minat dan rasa ingin tahu, pikiran dan penalaran, logika, bahasa, dan kebutuhan hidup manusia.

\section{LATIHAN SOAL}

Tunjukkan dan jelaskan peran atau fungsi hal-hal berikut ini dalam pembentukan pengetahuan manusia: pengalaman, ingatan, kesaksian, minat dan rasa ingin tahu, pikiran dan penalaran, logika, bahasa, dan kebutuhan hidup manusia. 


\section{BAB VI}

\section{SIKAP DASAR TERHADAP PENGETAHUAN DAN KEBENARAN}

\section{PENDAHULUAN}

1.1 Deskripsi Singkat

Bab ini mendiskusikan tentang pandangan dan sikap terhadap klaim kebenaran pengetahuan, meliputi sikap skeptisisme, subyektivisme, dan relativisme.

\subsection{Relevansi}

Melalui bab ini mahasiswa diharapkan memiliki pemahaman dan wawasan tentang ragam klaim kebenaran pengetahuan manusia sehingga dapat bersikap lapang dada serta toleran dalam menghargai perbedaan.

\subsection{Kompetensi Dasar}

a. Mahasiswa mampu menyebutkan macam sikap dan klaim kebenaran pengetahuan manusia.

b. Mahasiswa mampu menjelaskan sikap skeptisime terhadap pengetahuan manusia.

c. Mahasiswa mampu menjelaskan sikap subyektivisme terhadap pengetahuan manusia.

d. Mahasiswa mampu menjelaskan sikap relativisme tentang pengetahuan manusia.

e. Mahasiswa mampu bersikap dewasa dalam berinteraksi dengan ragam pandangan dan klaim pengetahuan.

\subsection{Indikator}

1. Mahasiswa dapat menyebutkan pokok-pokok dasar pengetahuan manusia.

2. Mahasiswa dapat menjelaskan konstruksi atau pilar-pilar yang menopang pengetahuan manusia.

Agar tujuan pengkajian dalam bab ini tercapat secara efektif, maka pembelajaran akan dibagi menjadi 2 (dua) bagian, yaitu bagian pertama bersifat eksposisi naratif tentang sikap dasar manusia terhadap pengetahuan dan kebenaran, sementara bagian kedua bersifat praktik eksploratif untuk mengembangkan sikap toleran terhadap keragaman.

\section{SIKAP DASAR TERHADAP PENGETAHUAN DAN KEBENARAN}


Secara sederhana, pandangan dan sikap terhadap klaim kebenaran pengetahuan dapat digambarkan sebagai berikut:

\author{
Skeptisisme $>$ Fallibilisme $<$ Dogmatisme \\ Subyektivisme $>$ Intersubyektivisme $<$ Obyektivisme \\ Relativisme $>$ Probabilisme $<$ Absolutisme
}

\title{
2.1 Skeptisisme
}

Sikap ini menandaskan bahwa fenomena kekeliruan dan juga perbedaan pendapat adalah inheren dalam pengetahuan manusia. Skeptisisme (dari kata skeptomai) muncul dalam bentuk menyangsikan klaim kebenaran/menangguhkan persetujuan/ penolakan tentangnya. Manusia tentu tak luput dari kesangsian, maka dari itu perlu sikap kritis untuk mencari bukti yang memadai. Macamnya dapat berupa sikap bahwa: tak ada yang pasti selain yang sedang dialami secara langsung (Arcesilaus \& Carneades); atau menangguhkn penilaian tentang hakikat kenyataan, hidup sebatas apa yang tampak dan memelihara ketenangan pikiran (Pyrrho \& Sextus Empiricus). Bisa juga berupa sikap mengingkari secara mutlak/universal kemungkinan manusia tahu. Atau hanya sekedar menyangsikan secara nisbi/particular atas kemampuan manusia bisa tahu pasti.

\subsection{Subyektivisme}

Sikap ini memandang bahwa satu-satunya yang kita ketahui secara pasti adalah diri sendiri dan kegiatan sadarnya yang dialami secara langsung. Pada titik yang ekstrim, sikap ini bisa mengantar seseorang pada solipsisme, yakni hidup dalam dunia kebenarannya sendiri atau sendirian pada dirinya.

\subsection{Relativisme}

Sikap ini mengingkari adanya dan diketahuinya kebenaran yang obyektif dan universal oleh manusia. Yang ada dalam pandangannya hanyalah kebenaran yang bersifat relatif. Sikap ini menarik karena bisa mengantar seseorang makin sadar akan kemajemukan; ditemukan dalam pengalaman personal; dan merupakan jalan mudah hindari konflik. Macamnya ada relativisme subyektif (subyektivisme), relativisme budaya (tidak ada kebenaran obyektif / universal; kebenaran senantiasa bersifat lokal, kontekstual, konvensional), dan relativisme konseptual (didasarkan pada relativitas kerangka konseptual; tidak ada tolak ukur yang netral dan universal untuk semua paradigma).

Ada juga beberapa keberatan terhadap relativisme karena dianggap melakukan kekeliruan dalam nalar pengecualiannya serta dalam pengandaian referensi yang tak berujung. Kelebihan relativisme: melawan sikap rasional ekstrem; pengakuan atas keterbatasan manusia; tekankan sifat relasional dan kontekstual pengetahuan manusia. Yang patut diingat, kepastian mutlak memang tidak mungkin, tapi tidak berarti bahwa semua pengetahuan manusia pantas diragukan (skepsisme mutlak ditolak). Subyek mengetahui itu 
aktif tidak hanya pasif, jadi pengetahuan tidak melulu bersifat subyektif (subyektivisme mutlak ditolak). Pengetahuan bersifat relasional dan kontekstual, tidak berarti yang universal dan obyektif tidak mungkin.

\section{PRAKTEK MEMBANGUN SIKAP TOLERANSI TERHADAP PERBEDAAN PANDANGAN DAN KEYAKINAN}

Dalam bagian ini kelas dibagi dalam tiga kelompok yang akan bermain peran sebagai pendukung dari tiga model sikap terhadap pengetahuan manusia, yaitu skeptis, subyektif, dan relativis. Interaksi dilakukan melalui suatu forum diskusi yang akan membincang suatu kasus aktual tentang pendidikan --yang disepakati dalam kontrak belajar di kelas-- yang dikategorikan 'kontroversial' dan bisa memantik munculnya perbedaan pandangan dan penyikapan.

Salah satu contoh tema yang bisa diangkat dalam praktik ini adalah isu yang dimuat dalam berita Tirto.id tentang sistem zonasi penerimaan siswa baru. Berikut isi lengkap beritanya:

\section{Pro Kontra Sistem Zonasi dalam Penerimaan Siswa Baru}

\section{Juli 2017}

Sistem zonasi dinilai cukup baik untuk mengatasi persoalan ketimpangan kualitas pendidikan.

Tirto.id - Sistem zonasi dalam penerimaan siswa baru diatur dalam Permendikbud No 17 tahun 2017 tentang Penerimaan Peserta Didik Baru (PPDB). Anggota Pimpinan Ombudsman RI Ahmad Suaedy menyebutnya sebagai sistem yang tepat untuk menghapus perspektif favoritisme sekolah di masyarakat. "Itu yang saya sebut perspektif masyarakat tentang favoritisme. Masyarakat sekarang ini berangan-angan anaknya semua masuk sekolah favorit dengan segala cara," kata Suaedy di kantor Ombudsman RI, Kuningan, Kamis (13/7/2017).

la menilai hal itu sebagai tidak adil karena menciptakan sekolah-sekolah favorit yang mayoritas berada di kota-kota besar atau di pusat kota. "Itu sebenarnya tidak adil dan tidak merata. Semua orang akan lari ke sekolah tersebut. Kenyataannya sekolah favorit itu hanya ada di kota-kota besar dan di pusat-pusat kota," katanya. Ombudsman RI sendiri, kata Suaedy, dalam pengawasannya terkait sistem PPDB menemukan fakta ketimpangan itu. Misalnya, ada empat sekolah favorit yang lokasinya berada dalam satu kelurahan di salah satu pusat kota di negeri ini. "Sedangkan yang di pinggiran tidak terfasilitasi. Ini yang harus dipindahkan ke pinggiran. Membuat sekolah yang bagus di sana dengan sistem zonasi," kata Suaedy.

Ketimpangan semacam itu, kata Suaedy, tidak lain diakibatkan karena sekolah-sekolah yang dianggap favorit tersebut leluasa memilih calon siswa degan nilai yang paling tinggi. Mereka sangat mungkin mengatrol nilai akreditasi sekolah karena akreditasi memang -- salah satunya -- mengacu kepada komponen prestasi siswa. "Persaingan yang favorit dan yang tidak favorit atau antara yang favorit satu dan dua jadinya tidak seimbang. Nanti yang favorit akan terus favorit. Dari segi inputnya, mereka bisa dengan leluasa memilih yang memiliki nilai paling tinggi," jelas Suaedy. Suaedy tidak setuju dengan kritik atas sistem zonasi 
yang menganggap sistem zonasi ditentukan oleh jarak bukan prestasi. Menurutnya, tidak semua siswa yang diterima dalam sistem zonasi karena jarak rumahnya dengan sekolah. "Kalau kuota rombongan belajar di zona itu sudah penuh, nanti juga diurutkan sesuai NEM-nya, kok. Kalau yang tidak lolos akan difasilitasi dengan direkomendasikan ke sekolah lain yang masih satu zona atau yang berada di zona lain," katanya.

Dengan tegas Suaedy menyatakan, bila sistem zonasi tidak diberlakukan maka proses desentralisasi yang sudah berjalan selama lebih kurang 20 tahun di negeri ini tidak berimbas pada dunia pendidikan. "Berarti selama 20 tahun desentralisasi di negeri ini, dalam dunia pendidikan belum mengarah ke situ," katanya. Akibatnya, kata Suaedy, bisa berpengaruh pada pembangunan karakter siswa dalam dunia pendidikan, tidak hanya pada sisi pemerataan sekolah saja. "Nah, selama ini anak-anak yang punya nilai yang baik itu orang kaya, sesuai dengan [akses pada] fasilitas yang dimiliki. Maka ini yang membuat, kalau kita bicara soal pendidikan karakter, yang merusak karakter. Kalau kita merasa lebih bangga [karena masuk sekolah favorit], nah yang di bawah-bawahnya merasa tidak sama," kata Suaedy. Untuk itu, menurut Suaedy, Ombudsman RI sejak tahun lalu telah mendorong Kemendikbud agar menerapkan sistem zonasi sebagai sebuah langkah pemerataan kualitas pendidikan di Indonesia. Dan hal itu kemudian diwujudkan dalam Permendikbud No 17 Tahun 2017. "Meski begitu ada aturan-aturan daerah yang belum bisa diubah terkait itu dan ada modifikasi. Kalau modifikasi itu, menurut ombudsman, masih bisa dimaklumi. Misalnya dari 90 persen dari zonasi jadi 46 persen. Tapi ada juga daerah yang berusaha keras untuk menerapkan secara strict permendikbud soal yang 90 persen itu, "kata Suaedy.

\section{Problem Zonasi untuk Memecahkan Ketimpangan}

Inspektur Jenderal Kemendikbud Daryanto mengemukakan bahwa sistem zonasi menempati posisi teratas dalam daftar aduan-aduan yang dikirim masyarakat ke Kemendikbud. Dari 240 aspirasi yang diterima selama Juni-Juli 2017, 170 di antaranya terkait masalah PPDB yang dilandaskan pada sistem zonasi. Mengenai hal itu, Pengamat Pendidikan Budi Trikoryatnto menganggap sistem zonasi tidak sepenuhnya menutup celah ketimpangan dalam dunia pendidikan. "Karena sistem zonasi, orang tua akan memasukkan anaknya ke sekolah yang paling dekat. Di situ, akhirnya, ada persaingan yang lebih sengit. Permasalahan utama adalah anak kurang pintar tidak akan bisa masuk sekolah yang terbaik dan harus menempuh pendidikan di sekolah gurem," kata Budi saat dihubungi Tirto (13/7).

Sedangkan, menurut Budi, anak yang kurang pintar juga punya kesempatan untuk bersekolah di sekolah favorit sebagaimana yang pintar. "Sekolah yang baik harus bisa juga mendidik anak yang kurang pintar," kata Budi. Untuk itu, menurut Budi, solusinya adalah dengan cara melakukan undian saat PPDB. "Caranya? Pendaftar diundi di depan para orangtua. Dipilih secara acak. Jangan dipilih-pilih anak yang hasil UN-nya yang tinggi saja," jelas Budi. Ditanya apakah sistem undian tidak akan membuka peluang kecurangan dari pihak sekolah, Budi menolaknya. Karena, menurut Budi, undian dilakukan secara terbuka di hadapan para calon wali murid. "Tidak akan, karena diundi di hadapan orangtua anak yg mendaftar," katanya. 
Di sisi lain, praktisi pendidikan, Prof. Arief Rachman, menyatakan persaingan memang tidak dapat dielakkan dalam sistem zonasi. Tapi, menurutnya, itu bukan menjadi sebuah masalah untuk diterapkan. la menegaskan tidak perlu sistem lain seperti undian. "Mencari sekolah, kan, seperti mencari istri. Tentu saja saya akan memilih yang terbaik. Tapi ini, kan, bukan cuma perkara selera. Ada banyak hal yang harus diperhitungkan. Kualitas sekolahnya, pendidiknya, termasuk jarak. Jadi, persaingan tidak bisa dielakkan. Menurut saya, sistem zonasi ini sudah baik untuk pemerataan," ujar Guru Besar Universitas Negeri Jakarta ini. Lebih lanjut ia memberi contoh bahwa di Jakarta hanya SMAN 8 saja yang dianggap baik. SMA tersebut berada di Bukit Duri, Tebet, yang secara administratif masuk wilayah Jakarta Selatan. "Saya, misalnya, sebagai orang Rawamangun menginginkan juga ada SMP, SMA, SMK yang baik di daerah saya," kata Arief saat dihubungi Tirto, Kamis (13/7/2017). Rawamangun sendiri berada di wilayah Jakarta Timur.

Dalam penerapannya pun, menurut sosok yang pernah memimpin LabSchool ini, sistem zonasi sah saja untuk diterapkan di semua jenjang pendidikan dari SD sampai SMA. Karena, menurutnya, sistem ini bukan perkara layak atau tidaknya untuk diterapkan di jenjang pendidikan tertentu. "Kalau bicara layak atau tidak diterapkan di semua jenjang, itu berarti bicara patut dan tidak, kan? Menurut saya sistem ini baik. Tidak masalah diterapkan di semua jenjang pendidikan. Ini sekali lagi bukan soal jarak, tapi pemerataan kualitas pendidikan. Kecuali universitas, karena kuota penerimaannya juga hanya 12,5 persen. Jadi, kalau mau masuk fakultas kedokteran yang baik bisa di UI, dan itu lumrah," jelas Arief.

Reporter: M. Ahsan Ridhoi

Penulis: M. Ahsan Ridhoi

Editor: Zen RS

Sumber: https://tirto.id/pro-kontra-sistem-zonasi-dalam-penerimaan-siswa-baru-csEh.

Mahasiswa per-kelompok selanjutnya membuat simpulan dari diskusi yang merupakan hasil analisis tentang faktor-faktor yang memicu lahirnya perbedaan pendapat dan sikap di antara peserta diskusi mengenai 'kasus' yang dikaji.

\section{RINGKASAN BAB IV (BAGIAN I)}

4.1 Klaim pengetahuan dan kebenaran melahirkan beberapa model sikap manusia dalam menanggapinya. Secara sederhana ada tiga varian bisa disebutkan: (1) Skeptisisme; (2) Subyektivisme; dan (3) Relativisme. Skeptisisme menyangsikan klaim kebenaran/ menangguhkan persetujuan/penolakan tentang pengetahuan manusia. Subyektivisme memandang bahwa satu-satunya yang kita ketahui secara pasti adalah diri sendiri dan kegiatan sadarnya yang dialami secara langsung. Relativisme mengingkari adanya dan diketahuinya kebenaran yang obyektif dan universal oleh manusia. Yang ada hanya kebenaran yang relatif. 
4.2 Setiap persoalan selalu terbuka untuk dipahami dan disikapi secara berbeda oleh manusia. Maka dari itu, setiap orang patut bersikap lapang dada dan toleran namun kritis terhadap perbedaan pendapat dalam suatu perkata tertentu.

\section{LATIHAN SOAL}

1. Jelaskan sikap skeptisisme tentang klaim kebenaran pengetahuan manusia!

2. Jelaskan sikap subyektivisme tentang klaim kebenaran pengetahuan manusia!

3. Jelaskan sikap relativisme tentang klaim kebenaran pengetahuan manusia!

4. Jelaskan faktor-faktor yang signifikan dapat memicu lahirnya perbedaan pendapat dan sikap mengenai suatu klaim kebenaran pengetahuan! 


\section{BAB VII}

\section{STRUKTUR DASAR KEGIATAN MENGETAHUI}

\section{PENDAHULUAN}

1.1 Deskripsi Singkat

Bab ini mendiskusikan tentang struktur dasar kegiatan-mengetahui manusia. Pertanyaan kuncinya adalah bagaimana manusia bisa tahu.

1.2 Relevansi

Melalui bab ini mahasiswa diharapkan memiliki pemahaman dan wawasan tentang struktur dasar kegiatan-mengetahui manusia.

\subsection{Kompetensi Dasar}

a. Mahasiswa mampu menjelaskan bagaimana manusia bisa tahu atau bisa memiliki pengetahuan.

b. Mahasiswa mampu menjelaskan beberapa karakter atau sifat dari pengetahuan manusia.

1.4 Indikator

a. Mahasiswa dapat menjelaskan bagaimana manusia bisa tahu atau bisa memiliki pengetahuan.

b. Mahasiswa dapat menjelaskan beberapa karakter atau sifat dari pengetahuan manusia.

\section{STRUKTUR DASAR KEGIATAN MENGETAHUI}

Sebagai makhluk yang kompleks, dalam hidupnya manusia dipengaruhi banyak hal. Mulai dari level mikro biologis hingga level makro sejarah dan budaya. Manusia tak bisa melepaskan dirinya dari aktivitas biologis tubuhnya sebagaimana juga ia tak mungkin terbebas dari pengaruh sejarah dan budaya dimana ia tumbuh kembang bersamanya. Jadi, untuk memahami seorang individu secara lebih komprehensif diperlukan tidak hanya penguasaan tentang bagaimana cara kerja tubuh manusia, tetapi juga aspek psikologis serta konteks sejarah dan budaya dimana ia berada. Disiplin keilmuan Psikologi mengenalnya dengan istilah triple bookkeeping atau tiga ranah yang mengakumulasi data pribadi seseorang, yaitu ranah biologis, psikologis, serta historis dan kultural (Westen, 1996).

Maka dari itu, untuk memahami aktivitas berfikir manusia, tidak cukup dengan mendedah aspek mentalnya saja. Aktivitas berfikir manusia tidak bisa dibatasi hanya sebagai aktivitas psikologis semata. Bagaimanapun, sebagai aktivitas yang tak lepas dari keutuhan entitas seorang manusia, berfikir mengandaikan adanya interaksi setidaknya antara tiga ranah tersebut di atas. 
Ketika manusia berfikir, aktivitas ini tentu sangat bergantung pada kemampuan sel-sel dan proses circuit syaraf otaknya. Murid TK, misalnya, belum mampu mengerjakan soal-soal aljabar karena circuit syaraf sel-sel otaknya yang berfungsi untuk berfikir abstrak belum berkembang matang. Kondisi emosional juga berpengaruh dalam aktivitas berfikir manusia. Seorang remaja yang baru mengalami diputus cinta, kondisi emosionalnya sedikit banyak akan mempengaruhi aktivitas berfikirnya.

Kegiatan mengetahui manusia tidak dapat dilepaskan dari natur alamiah yang ada pada diri manusia itu sendiri. Dalam naturnya, manusia memiliki setidaknya tiga ranah pribadi, meliputi ranah kognisi, afeksi, psikomotorik. Secara psikologis, manusia juga tidak dapat dilepaskan dari struktur psikisnya yang dalam teori Freudian dibedakan menjadi id, ego, super ego. Kegiatan mengetahui selalu merupakan kegiatan sadar. Prosesnya dapat berlangsung secara langsung atau tidak langsung (reflektif). Mengandaikan adanya interaksi antara subyek dan obyek.

Pengetahuan manusia pada gilirannya akan bersifat intensional dalam artian bahwa pengetahuan manusia senantiasa adalah pengetahuan tentang sesuatu (knowledge of). Subyektivitas dan obyektivitas akrab menjadi isu penting dalam khazanah pengetahuan manusia. Di sini, obyek yang diketahui sifatnya adalah real / nyata, eksternal terhadap subyek, berbeda dari subyek, tidak harus bersifat fisik, intersubyektif, dan dapat dijelaskan secara rasional.

\subsection{Kesadaran dan Kesengajaan}

Menyadari suatu obyek tidak berbanding lurus dengan mengetahuinya. Menyadari sesuatu tidak melulu memandang / mengamatinya. Kesadaran tidak harus selalu disengaja, bisa merupakan refleks. Dengan demikian, kegiatan mengetahui bisa dirumuskan sebagai persamaan: "Kegiatan mengetahui = kesadaran + kesengajaan"; "Kegiatan mengetahui = pikiran + kehendak." Ringkasnya, kegiatan mengetahui adalah proses nalar mencapai sesuatu yang dinilai secara bertanggung jawab sebagai benar.

\subsection{Struktur Kegiatan Mengetahui}

Pertama, pengalaman keindraan / pencerapan inderawi (sense perception). Kedua, pemahaman (understanding); konseptualisasi pola dan struktur keterpahaman (the intelligible structure) yang imanen dalam obyek yang tersaji dalam tahap pertama. Ketiga, pertimbangan dan penegasan putusan (judgment); bisa berupa peneguhan / penyangkalan; benar / salah; baik / buruk; indah / jelek; tepat / meleset; dan seterusnya. Intinya ini adalah penalaran atas pengalaman dan pemahaman sebelumnya. Jadi sifatnya bertahap, meningkat, kumulatif, dan ajeg.

\section{RINGKASAN}

Kegiatan mengetahui adalah proses nalar mencapai sesuatu yang dinilai secara bertanggung jawab sebagai benar. Kegiatan mengetahui manusia tidak dapat dilepaskan dari natur alamiah yang ada pada diri manusia itu sendiri. Pengetahuan manusia senantiasa akan bersifat intensional, artinya selalu merupakan 
pengetahuan tentang sesuatu (knowledge of). Dalam prosesnya, kegiatan mengetahui tersebut bersifat bertahap, meningkat, kumulatif, dan ajeg.

\section{LATIHAN SOAL BAB V}

1. Bagaimana manusia bisa tahu? Jelaskan!

2. Sebutkan dan jelaskan beberapa karakter atau sifat dari pengetahuan manusia! 


\section{BAB VIII}

\section{PENGALAMAN INDERAWI}

\section{PENDAHULUAN}

\subsection{Deskripsi Singkat}

Bab ini mendiskusikan tentang peran pengalaman inderawi dalam kegiatan-mengetahui manusia beserta permasalahannya.

\subsection{Relevansi}

Melalui bab ini mahasiswa diharapkan memiliki pemahaman dan wawasan tentang peran pengalaman inderawi dalam kegiatan-mengetahui manusia. Lebih lanjut, mereka juga mampu menganalisis ragam permasalahan yang timbul berkenaan dengan peran pengalaman inderawi dalam kegiatan-mengetahui manusia tersebut.

\subsection{Kompetensi Dasar}

a. Mahasiswa mampu menjelaskan peran pengalaman inderawi dalam kegiatan-mengetahui manusia.

b. Mahasiswa mampu menganalisis ragam permasalahan yang timbul berkenaan dengan peran pengalaman inderawi dalam kegiatan-mengetahui manusia.

1.4 Indikator

a. Mahasiswa dapat menjelaskan peran pengalaman inderawi dalam kegiatan-mengetahui manusia.

b. Mahasiswa dapat menganalisis ragam permasalahan yang timbul berkenaan dengan peran pengalaman inderawi dalam kegiatan-mengetahui manusia.

\section{PERAN DAN PERMASALAHAN PENGALAMAN INDERAWI}

Pengalaman inderawi adalah serangkaian akibat atau kesan-kesan pada subyek penahu yang penyebabnya dapat dirunut kembali ke kegiatan indera. Pengalaman inderawi selalu berjalin dengan akal, dorongan untuk mengerti dan mengetahui. Maka dari itu, pengalaman kognitif manusia selalu bersifat indrawi-akali (sensitive-intellective). Persepsi adalah ambang pengenalan, suatu kesadaran akan apa yang dipersepsikan dan di dalamnya sudah termuat konseptualisasi. Apa yang kita sadari melalui indera kita dalam persepsi selalu merupakan "ini adalah sesuatu" (this such). Konseptualisasi ini menunjuk pada 
sesuatu yang kongkrit partikular ("ini") sekaligus penggolongannya dalam suatu kategori tertentu ("adalah sesuatu").

Terdapat tiga aspek pengalaman perceptual yang perlu dikenali perbedaannya: (1) Pengalaman perseptual yang secara aktual dihayati. Penghayatan ini bersifat inderawi sekaligus akali mengenai suatu obyek fisik beserta cirri-cirinya. Persepsi ini merupakan suatu pengenalan; (2) Persepsi. Tahap dalam pengalaman perseptual dimana kesatuan dalam satu obyek dengan bermacam-macam kualitas inderawi yang disampaikan melalui indera penerima diperoleh; (3) Penginderaan. Tahap awal transmisi kausal informasi inderawi yang tidak secara langsung tersadari.

\subsection{Indera}

Pancaindera yang dikenal meliputi penglihatan, pendengaran, pencecap, pembau, dan peraba. Kelima indera yang biasanya dikenal sebagai indera luar (external senses) ini berbeda satu sama lain dan acapkali berfungsi secara gabungan. Kualitas-kualitas terindera yang dialami melalui indera luar tersebut selanjutnya diproses kenali oleh daya indera dalam (internal senses) yang merupakan fungsi dari bagian cortex otak manusia. Lazimnya, yang termasuk indera dalam ini adalah: (1) indera pusat atau indera pemadu; (2) imajinasi; (3) ingatan; dan (4) daya estimatif. Daya indera pusat bekerja mempersepsi, membedakan dan menggabungkan penginderaan menjadi kesadaran yang padu tentang suatu obyek. Imajinasi berfungsi menghadirkan kembali atau mereproduksi secara inderawi (dalam kesadaran) suatu obyek yang tidak hadir pada organ penerima (indera luar). Ingatan menjadi daya yang menghadirkan kembali secara inderawi suatu obyek pengalaman masa lalu sebagai masa lalu. Sedangkan daya estimatif bekerja dalam perilaku instingtif, mengenali suatu obyek inderawi sebelum pembelajaran dan pemahaman. James E. Royce mengenalkan konsep "indera khusus" untuk menamai daya-daya yang memungkinkan kita mengalami suatu kualitas dari obyek material merangsang suatu organ penerima dalam diri kita. Indera khusus tersebut adalah: (1) Penglihatan, pendengaran, pencecap, pembau; (2) Indera-indera peraba (panas, dingin, halus, kasar, dsb.); (3) Indera penggerak (berkenaan dengan gerak anggota tubuh); (4) Indera keseimbangan (keseimbangan tubuh); dan (5) Indera-indera organic (terkait dengan rasa sakit, mual, haus, lapar, dsb.). Telaah yang lebih mendalam tentang indera akan menyadarkan kita betapa bahwa tiap indera yang kita miliki memiliki kompleksitas struktur sekaligus proses dari suatu fungsi yang sangat rumit. Jauh lebih mudah mengalami suatu pengalaman inderawi daripada harus menjelaskannya secara ilmiah. Tegasnya, pengalaman perceptual meruapakan suatu hal yang kompleks.

\subsection{Memaparkan dan Menjelaskan}

Dua kata ini adalah dua konsep yang berbeda. Pemaparan adalah suatu awal proses pemahaman atas suatu obyek. la merupakan suatu kegiatan pikiran dimana sajian inderawi yang berhubungan 
dengan subyek pengindera dipahami. Misal, "Saat ini saya sedang melihat matahari beranjak terbenam di balik bukit. Warnanya jingga." Penjelasan adalah tahap lanjutan kegiatan pikiran ketika pertanyaan muncul mengenai apa yang telah dipaparkan. "Benarkah matahari yang saya lihat itu berwarna jingga? Mengapa warnanya demikian? Apakah orang lain juga akan mendapatkan persepsi inderawi yang sama sebagaimana yang saya alami?" Jadi, memberi paparan atau pemerian tentang sesuatu yang kita alami secara inderawi tidak sama dengan memberi penjelasan tentang pengalaman itu.

\subsection{Mediasi dan Inferensi}

Suatu yang menghubungkan dua hal disebut mediasi. Sebuah soal filsafat umum: Apa dan bagaimana pengetahuan manusia bermediasi? Dikenal ada tiga macam mediasi: (1) Medium quod. Sesuatu yang sesuatu itu sendiri diketahui dan dalam mengetahui sesuatu itu sesuatu yang lain juga diketahui, semisal premis-premis silogisme yang mengantar kepada suatu simpulan; (2) Medium quo. Sesuatu yang sesuatu itu sendiri tidak disadari tetapi melaluinya sesuatu yang lain diketahui, semisal kacamata yang dipakai seseorang untuk melihat benda-benda; (3) Medium in quo. Sesuatu yang tidak disadari secara langsung dan yang di dalamnya diketahui sesuatu yang lain, semisal kaca spion kendaraan untuk mengenali kendaraan atau hal-hal lain di belakangnya. Dari ketiganya hanya jenis pertama yang langsung kita sadari. Dalam kegiatan mengetahui, yang secara langsung kita sadari adalah obyek itu sendiri. Dari penjelasan di atas, maka indera kita baik luar maupun dalam merupakan suatu medium quo melalui mana obyek fisik dapat hadir dalam kesadaran kita. Inferensi adalah proses penalaran atau aktivitas berfikir yang dilakukan secara sadar dari sesuatu yang sudah diketahui ke sesuatu yang belum diketahui. Alurnya merupakan gerak pemikiran dari premis-premis ke kesimpulan. Macamnya ada tiga: deduksi, induksi, dan abduksi. Deduksi adalah inferensi yang bila premis-premisnya benar, maka simpulannya pasti atau niscaya benar. "Semua mangga dalam karung itu adalah mangga manalagi. Mangga ini diambil dari karung itu. Maka, mangga ini adalah mangga manalagi." Induksi dan abduksi tidak menghasilkan simpulan yang bersifat niscaya, paling jauh hanya bersifat mentak atau barangkali (probable, kemungkinan). Induksi adalah inferensi yang membentuk suatu hipotesis sedemikian rupa sehingga apabila hipotesis itu benar, maka premis-premis darimana inferensi itu ditarik juga dengan sendirinya benar. "Mangga ini diambil dari karung itu. Mangga ini mangga manalagi. Maka, barangkali semua mangga dalam karung itu adalah mangga manalagi." Abduksi adalah inferensi yang menguji hipotesis dengan menarik konsekuensi sebagai sebuah prediksi dan mengujinya dalam pengalaman. "Semua mangga dalam karung itu adalah mangga manalagi. Mangga-mangga ini adalah mangga manalagi. Maka, ada kemungkinan bahwa mangga-mangga ini diambil dari karung itu."

\subsection{Realisme Langsung yang Bermediasi}


Diketahui di muka bahwa memberi paparan atau pemerian tentang sesuatu yang kita alami secara inderawi tidak sama dengan memberi penjelasan tentang pengalaman itu. Yang langsung kita sadari adalah obyek fisik beserta kualitas inderawinya dan bukannya proses fisik atau psikis yang mungkin menjelaskan pengalaman inderawi tersebut. Pencerapan inderawi tidak melibatkan inferensi. Adanya proses mediasi dalam proses mengetahui baru disadari ketika menjelaskan penyebab terjadinya pengalaman inderawi. Pandangan semacam ini dianut oleh faham realism langsung yang bermediasi (direct mediate realism). Garis besarnya sebagai berikut:

Berbeda dari faham idealism dan realisme tak langsung baik representasionalisme maupun fenomenalisme, obyek fisik di luar kita yang secara langsung kita sadari dan cerap (alami) secara inderawi adalah obyek fisiknya itu sendiri. Namun penting dicatat bahwa pengenalan suatu obyek itu merupakan proses yang bermediasi. Artinya, berbeda dari realisme naïf, ketidakcocokan antara obyek fisik itu sendiri dengan persepsi inderawi tetap dimungkinkan karena dimensi intensional subyek pengindera memang terlibat di dalamnya. Sehingga, daun yang berwarna hijau di siang hari bisa menjadi terlihat hitam di malam hari. Melampaui realisme kritis yang bersifat formal dan juga yang bersifat virtual, yang keduanya memahami obyektivitas pengetahuan sebagai apa yang secara empiris terberi dan melokalisir kegiatan mengetahui sebagai memandang sesuatu serta melaporkannya secara obyektif dan impersonal, realism langsung yang bermediasi memasukkan dimensi sosial (intersubyektivitas) dan kesejarahan (historisitas) pengetahuan manusia.

\section{RINGKASAN}

Pengalaman inderawi adalah serangkaian akibat atau kesan-kesan pada subyek penahu yang penyebabnya dapat dirunut kembali ke kegiatan indera. Pengalaman inderawi selalu berjalin dengan akal, dorongan untuk mengerti dan mengetahui. Maka dari itu, pengalaman kognitif manusia selalu bersifat indrawi-akali (sensitive-intellective). Terdapat tiga aspek pengalaman perseptual yang perlu dikenali perbedaannya: (1) Pengalaman perseptual yang secara aktual dihayati; (2) Persepsi; (3) Penginderaan. Pengalaman perseptual merupakan sesuatu hal yang kompleks. Ketika indera bersentuhan dengan indera, awal proses pemahaman atas suatu obyek adalah pemaparan. la merupakan kegiatan pikiran dimana sajian inderawi yang berhubungan dengan subyek pengindera dipahami. Penjelasan adalah tahap lanjutan kegiatan pikiran ketika pertanyaan muncul mengenai apa yang telah dipaparkan. Jadi, pengenalan suatu obyek itu merupakan proses yang bermediasi. Di sini, indera kita baik luar maupun dalam merupakan suatu medium quo melalui mana obyek fisik dapat hadir dalam kesadaran kita. Sementara inferensi adalah proses penalaran atau aktivitas berfikir yang dilakukan secara sadar dari sesuatu yang sudah diketahui ke sesuatu yang belum diketahui. Macamnya ada tiga: deduksi, induksi, dan abduksi.

\section{LATIHAN SOAL}

1. Jelaskan peran dan fungsi pengalaman inderawi dalam kegiatan-mengetahui manusia! 
2. Jelaskan maksud dari pernyataan bahwa pengetahuan manusia itu dalam prosesnya bermediasi!

3. Jelaskan macam-macam inferensi! 


\section{BAB IX}

\section{KONSEPTUALISASI}

\section{PENDAHULUAN}

\subsection{Deskripsi Singkat}

Bab ini mendiskusikan tentang peran konsep dalam kegiatan-mengetahui manusia beserta permasalahannya.

\subsection{Relevansi}

Melalui bab ini mahasiswa diharapkan memiliki pemahaman dan wawasan tentang peran konsep dalam kegiatan-mengetahui manusia. Lebih lanjut, mereka juga mampu menganalisis ragam permasalahan yang timbul berkenaan dengan peran konsep dalam kegiatan-mengetahui manusia tersebut.

\subsection{Kompetensi Dasar}

a. Mahasiswa mampu menjelaskan peran konsep dalam kegiatan-mengetahui manusia.

b. Mahasiswa mampu menganalisis ragam permasalahan yang timbul berkenaan dengan peran konsep dalam kegiatan-mengetahui manusia.

\subsection{Indikator}

a. Mahasiswa dapat menjelaskan peran konsep dalam kegiatan-mengetahui manusia.

b. Mahasiswa dapat menganalisis ragam permasalahan yang timbul berkenaan dengan peran konsep dalam kegiatan-mengetahui manusia.

\section{PERAN DAN PERMASALAHAN KONSEP}

Konsep bisa digambarkan sebagai suatu medium yg menghubungkan subyek penahu dan obyek yang diketahui; antara pikiran dan kenyataan. Dari sisi subyek, manifestasinya dalam bentuk kegiatan merumuskan atau menggolong-golongkan dalam pikiran. Dari sisi obyek merujuk pada isi kegiatan tersebut, yakni apa makna dari konsep. Hal ini sifatnya universal, baik langsung, yakni dapat dipredikasi secara univok (persis sama) dan distributif (satu satu), misalnya konsep 'manusia'; maupun yang tidak langsung dengan menyebut kelas atau golongan dan tidak dapat dipredikasikan pada individu, semisal konsep 'kemanusiaan'.

Konsep bisa jadi dikenali sebagai suatu kata yang memiliki makna (word given meaning). Tetapi konsep sejatinya adalah representasi mental yang bersifat umum dan abstrak dari sesuatu hal. Semakin tinggi tingkat anstraksi, maka semakin jauh dari kemungkinan untuk digambarkan secara fisik. Konsep 
memungkinkan adanya penyebutan sesuatu, penegasan putusan, dan karenanya pengetahuan manusia menjadi sesuatu yang mungkin. Pengetahuan secara logis mengandaikan bahwa konsep memiliki pendasaran dalam kenyataan obyek-obyek fisik. Dan secara umum, semuanya juga menjadi mungkin karena manusia dianugerahi kemampuan atau daya abstraksi.

Konsep terkait dengan tema lain dalam filsafat yaitu pernyataan (statement) atau proposisi (proposition) dan putusan (judgement). Untuk pernyataan dapat didefinisikan sebagai kalimat deklaratif, atau bagian dari kalimat, yang mampu memiliki nilai kebenaran, seperti benar (true) atau salah (false). Misalnya, pernyataan berikut ini:

- Jakarta adalah ibu kota Indonesia.

- Tiap orang yang lahir pada hari Rabu memiliki hidung mancung.

Terkadang, sebuah pernyataan dapat berisi satu atau lebih pernyataan lain sebagai bagian.

Proposisi adalah istilah yang kadang-kadang digunakan secara sinonim dengan pernyataan. Namun, kadang-kadang digunakan untuk menyebut sesuatu yang abstrak bahwa dua pernyataan berbeda namun mengekspresikan makna yang sama. Dalam penggunaan ini, misalnya kalimat bahasa Inggris, "She is beautiful", dan kalimat Bahasa Indonesia "Perempuan itu cantik", akan dianggap menyatakan ekspresi proposisi yang sama. Namun, sifat atau keberadaan proposisi sebagai makna abstrak masih merupakan masalah kontroversi filosofis.

Putusan adalah sesuatu yang mungkin kita ketahui, yaitu objek pengetahuan. Suatu putusan terbukti jika kita benar-benar mengetahuinya. Misal, kita membuat putusan bahwa "sekarang sedang hujan", karena kita memiliki bukti untuk itu. Dalam kehidupan sehari-hari, bukti semacam itu seringkali bersifat langsung: kita dapat melihat keluar jendela dan melihat bahwa hujan memang sedang turun. Namun kita juga bisa menghadapi situasi di mana bukti tidak langsung: kita menyimpulkan putusan dengan membuat kesimpulan yang benar dari putusan-putusan bukti lainnya. Dengan kata lain bahwa putusan terbukti jika kita memiliki bukti untuk itu.

\section{RINGKASAN}

Manusia memiliki kemampuan untuk mengabstraksikan realitas sebagai suatu representasi mental. Daya abstraksi inilah yang memungkinkan manusia melakukan konseptualisasi. Dengan konsep yang dimilikinya manusia mampu menyusun proposisi atau membuat pernyataan dan putusan yang dengannya pengetahuan menjadi tidak mustahil.

\section{LATIHAN SOAL}

Jelaskan peran dan fungsi konsep dalam kegiatan-mengetahui manusia! 


\section{BAB X}

\section{KEBENARAN}

\section{PENDAHULUAN}

1.1 Deskripsi Singkat

Bab ini mendiskusikan tentang permasalahan kebenaran dan kesalahan dalam kegiatan-mengetahui manusia. Untuk itu, pembahasan akan diperkaya dengan mengupas ragam teori yang menjelaskan tentang apa sesungguhnya kebenaran itu dan bagaimana suatu klaim kebenaran itu dibangun atau dijustifikasi.

\subsection{Relevansi}

Melalui bab ini mahasiswa diharapkan memiliki pemahaman dan wawasan mengenai diskursus seputar kebenaran dan permasalahannya. Dengan pengetahuan tersebut mahasiswa akan memiliki bekal untuk mampu menganalisis kegiatan-mengetahui manusia termasuk klaim kebenaran dan justifikasinya.

\subsection{Kompetensi Dasar}

a. Mahasiswa mampu menjelaskan konseptualisasi kebenaran dan kesalahan dalam kegiatan-mengetahui manusia.

b. Mahasiswa mampu menjelaskan ragam teori kebenaran berikut contohnya.

c. Mahasiswa mampu menjelaskan ragam teori justifikasi berikut konstruksi aplikasinya dalam bangun pengetahuan manusia.

1.4 Indikator

a. Mahasiswa dapat menjelaskan konseptualisasi kebenaran dan kesalahan dalam kegiatan-mengetahui manusia.

b. Mahasiswa dapat menjelaskan ragam teori kebenaran berikut contohnya.

c. Mahasiswa dapat menjelaskan ragam teori justifikasi berikut konstruksi aplikasinya dalam bangun pengetahuan manusia. 


\section{KEBENARAN DAN KEKELIRUAN DALAM PENGETAHUAN}

Dalam dunia ilmiah, klaim kebenaran pengetahuan adalah hal yang lazim. Namun yang perlu diingat bahwa kita dapat berbicara tentang kebenaran atau kekeliruan dalam pengetahuan apabila pengetahuan tersebut telah termanifestasikan dalam bentuk pernyataan atau proposisi dan juga putusan atau klaim. Kita belum bisa mengatakan sesuatu benar atau keliru dalam dirinya sendiri karena ide atau konsep yang diwakilinya hanyalah bahan mentah pengetahuan. Secara logis, kita tidak dapat mengatakan misalnya bahwa istilah 'manusia' adalah 'benar', kecuali jika kita secara tidak akurat mendefinisikan 'kebenaran' sebagai, katakanlah, 'omnivora'. Meskipun demikian, ketika kita mengekspresikan hubungan antara atau di antara gagasan -dengan kata lain, ketika kita membuat putusan atau menyusun proposisi- maka kita baru dapat berbicara tentang kebenaran atau kekeliruan. "Manusia adalah omnivora" adalah penilaian yang menyatakan hubungan antara 'manusia' dan 'omnivora' dan dalam kasus ini, proposisi tersebut benar.

Kebenaran mengacu pada kesesuaian proposisi dengan kenyataan, sedangkan kekeliruan, ketidaksesuaian. Jika apa yang diungkapkan dalam proposisi cocok dengan kenyataan, itu benar; jika tidak, itu salah atau keliru. Pernyataan, "Sukarno adalah presiden pertama Indonesia" adalah benar; sementara proposisi, "Megawati adalah istri Sukarno" adalah keliru. Dengan demikian, barometer kebenaran adalah korespondensi putusan dengan kenyataan.

Namun, ada proposisi yang dianggap benar berdasarkan kebenaran atau kekeliruan pernyataan lain yang dikonfirmasi. Kebenaran mereka dijamin oleh proses penalaran yang disebut 'inferensi'. Misalnya, ketika kita menerima benar bahwa "Rossa adalah perempuan", maka kita juga dapat menegaskan bahwa "Rossa adalah manusia". Jadi juga dianggap sebagai jalan menuju kebenaran, inferensi dengan cara menyimpulkan kebenaran (atau kekeliruan) dari satu atau lebih proposisi yang relevan.

\section{TEORI-TEORI KEBENARAN}

Sering dikatakan bahwa setidaknya ada lima teori kebenaran utama, yaitu: teori korespondensi, teori koherensi, teori pragmatis, teori redundansi, dan teori semantik (Walker, 2017). Teori korespondensi kebenaran menyatakan bahwa untuk suatu putusan (atau, katakanlah, proposisi) dapat dinyatakan benar apabila hal itu sesuai dengan fakta. Teori koherensi kebenaran menyamakan kebenaran suatu putusan apabila memiliki koherensi dengan keyakinan yang lain. Teori kebenaran pragmatis agak mirip dengan teori koherensi. Teori ini menyatakan bahwa kebenaran suatu kepercayaan adalah masalah apakah hal itu terbukti dapat 'bekerja' atau membuahkan hasil sebagaimana yang diharapkan dalam pengalaman kita. Jadi dengan demikian, teori pragmatis juga menjadikan kebenaran sebagai masalah koherensi, tetapi koherensi dengan pengalaman masa depan. Untuk teori redundansi, soal kebenaran bukanlah teori tentang apa yang terkandung dalam kebenaran itu sendiri (consist in), tetapi sebuah teori tentang makna kata-kata 'benar' (the meaning of the words 'is true'). Jadi berbeda dengan para ahli teori korespondensi yang biasanya 
memusatkan perhatian pada kebenaran yang terkandung di dalamnya dan bukan dengan analisis makna sebagaimana teori redundansi ini. Adapun teori semantik kebenaran melakukan tugasnya dengan memberikan seperangkat aksioma terbatas, dan seperangkat aturan derivasi yang memungkinkan seseorang untuk menyimpulkan dari aksioma sebuah teorema dari bentuk yang diperlukan - "s adalah benar jika $p$ " untuk setiap kalimat bahasa. Di sini $s$ menunjuk kalimat bahasa yang sedang diperiksa; ia melakukan ini dalam hal strukturnya, menunjukkannya sebagai gabungan ekspresi bahasa-obyek yang lebih sederhana.

\section{TEORI-TEORI JUSTIFIKASI KEBENARAN}

Apa yang kita lihat bentuk dan warnanya, dengar suaranya, cium baunya, rasakan kondisinya, dan cicipi rasanya adalah apa yang kita persepsikan (perceive). Ketika kita mendeskripsikan pengalaman kita bahwa ada padang rumput yang hijau di hadapan kita, ada burung yang tengah bernyanyi, bau aroma dari bunga-bunga mawar, gelas yang dingin saat disentuh jemari kita, dan teh rasa mint saat kita cicipi, sebenarnya kita tengah mengekspresikan apa yang kita percaya (believe). Pengalaman tersebut menjadi dasar yang membuktikan (justification) kepercayaan (beliefs) kita. Mempercayai pengetahuan semacam ini tentu sesuatu yang baik daripada mempercayai sesuatu yang mungkin kita persepsi dari apa yang kita alami di alam mimpi.

Selanjutnya yang perlu dipahami bahwa menjadi terbukti (being justified) berbeda dengan menjadi jernih (being purified). Yang kedua tersebut, misal tentang isu-isu yang kontroversial, membutuhkan proses penjelasan untuk menjernihkan (purification) bahwa suatu pendapat bisa dipercaya dengan mengemukakan alasan-alasannya. Tetapi yang pertama sebagaimana contoh di atas tampaknya tidak membutuhkan proses ini karena sudah memiliki apa yang disebut sebagai properti menjadi terbukti (property of being justified) atau kerterbuktian (justifiedness). Ada sesuatu tentang atau pada diri mereka yang secara alamiah dan patut bagi kita sebagai manusia normal yang berakal untuk mempercayainya.

Kesadaran pada keterbatasan manusia dan kemungkinan atau peluang salah dalam pengetahuan kita sepatutnya tidak mengarahkan kita menjadi selalu berada dalam kondisi meragu atau tidak nyaman dan tidak aman dalam hidup kita. Kesadaran dan pengakuan kita atas hal tersebut cukup mengingatkan kita bahwa kita tidak sepatutnya bersikap absolut pada apa yang kita ketahui sebagai benar atau bersikap tertutup terhadap kebenaran yang dapat hadir di samping kita atau di kemudian hari yang suatu ketika dapat meluruskan arah pandang atau arah langkah kita tentang sesuatu. Dengan pengetahuan yang kita miliki dari sumber-sumber dan cara-cara yang mungkin dapat memberi kita dasar yang cukup memadai untuk menjalani kehidupan ini dengan cara yang positif dan optimis. Kita percaya bahwa kita bisa mengetahui sesuatu. Pengetahuan itu meski tidak absolut, sebagai manusia dan bukan Tuhan kita bisa memuaskan rasa tahu dan menenangkan rasa ragu atau cemas tentang hidup ini. Toh untuk menjadi bahagia sebagai manusia, kita tidak dituntut untuk menjadi Tuhan yang mengetahui segala sesuatu secara pasti dan absolut. Cukup dengan mengetahui didasarkan pada alasan-alasan yang memadai dan patut kita percayai sebagai benar sebagai makhluk normal yang berakal. 
Justifikasi yang dimaksudkan di sini mencakup proses dan juga hasil. Proses pembuktian bahwa suatu pengetahuan itu memang patut dipercaya sebagai benar. Hasil dari pembuktian itu berupa putusan bahwa suatu pengetahuan memang benar dan karenanya patut dipercaya. Kita tidak bisa membayangkan bahwa orang yang skeptis secara absolut bisa menjalani hidup ini dengan rasa tenang, nyaman, dan aman. Bagaimanapun sebagai manusia, kita membutuhkan keamanan, ketenangan, kenyamanan epistemologis. Karena semua itu adalah elemen-elemen dasar dari kebahagiaan. Sekalipun tidak tepat jika skeptisisme adalah negatif secara absolut. Dalam lingkup tertentu, kita memang perlu mengambil sikap dan posisi skeptis untuk menstimuli nalar kita mencari jawaban yang benar dari sesuatu yang menuruk akal sehat kita memang patut diragukan dan dipersoalkan kebenaran dan dasar-dasar justifikasinya.

Sebagai manusia yang berakal, banyak hal yang ingin kita ketahui. Kita juga peduli tentang apa yang kita ketahui. Bahwa kita menginginkan apa yang kita ketahui atau pengetahuan kita itu adalah tidak salah atau menipu. Kita juga kerap berharap bahwa kita bisa menemukan atau mencapai pengetahuan pada tingkatan yang memuaskan hati dan akal pikiran kita untuk percaya. Tidak semata meniru atau ikut-ikutan apa yang orang lain pikirkan dan lakukan dalam hidupnya. Epistemologi memberi menu buat kita untuk memikirkan hal ini. Tentang pengetahuan dan juga justifikasi kebenarannya (Audi, 2003).

Menjelaskan dan mengevaluasi teori-teori pembenaran itu bisa merupakan laku yang menakutkan. Tidak hanya karena ada sejumlah teori pembenaran yang berbeda, tetapi karena ada juga perbedaan radikal di antara para pakar epistemologi mengenai bagaimana mereka memahami apa yang ditawarkan teori semacam itu. Fumerton (2006) menawarkan ikhtisar beberapa posisi penting tentang sifat justifikasi. Ini dimulai dengan mengisolasi justifikasi epistemik dari justifikasi nonepistemik. Ini juga membedakan antara having justification atau memiliki justifikasi untuk keyakinan dan having a justified belief atau memiliki keyakinan yang dibenarkan, dengan alasan bahwa yang pertama secara konsep lebih fundamental.

Adapun beberapa teori justifikasi kebenaran yang bisa dikenali antara lain: fondasionalisme, kontekstualisme, koherentisme, dan teori 'campuran' yang menggabungkan aspek koherentisme dan fondasionalisme. Berikut penjelasan ringkas beberapa teori mengenai justifikasi kebenaran tersebut.

\subsection{Fondasionalisme}

Teori ini termasuk yang paling popular. Bagi kaum fondasionalis, semua pembenaran (dan semua pengetahuan) bertumpu pada dasar pembenaran noninferensial (pengetahuan). Kaum fondasionalis ingin membandingkan pembenaran/ pengetahuan inferensial dengan semacam pembenaran/ pengetahuan yang tidak didasari inferensi, baik secara keseluruhan atau sebagian, karena memiliki keyakinan lain yang dibenarkan (other justified beliefs) atau memiliki pengetahuan lain (other knowledge).

\subsection{Kontekstualisme}

Dalam istilah yang sangat umum, kontekstualisme epistemologis menyatakan bahwa apakah seseorang tahu yang entah bagaimana relatif terhadap konteks. Fitur-fitur tertentu dari konteks - 
fitur seperti niat dan anggapan anggota dari konteks percakapan - membentuk standar yang harus dipenuhi seseorang agar keyakinan seseorang dianggap sebagai pengetahuan. Hal ini memungkinkan untuk kemungkinan bahwa konteks yang berbeda menetapkan standar epistemik yang berbeda, dan para kontekstualis selalu berpendapat bahwa standar itu sebenarnya berbeda dari konteks ke konteks. Dalam beberapa konteks, standar epistemik luar biasa tinggi, dan sulit, jika bukan tidak mungkin, keyakinan kita dianggap sebagai pengetahuan dalam konteks seperti itu. Namun, dalam kebanyakan konteks, standar epistemik relatif rendah, dan kepercayaan kita dapat dan sering dianggap sebagai pengetahuan dalam konteks ini. Argumen utama untuk kontekstualisme epistemologis mengklaim bahwa kontekstualisme merupakan teori paling baik dalam menjelaskan penilaian epistemik kita - itu menjelaskan mengapa kita menilai dalam sebagian besar konteks bahwa kita memiliki pengetahuan dan mengapa kita menilai dalam beberapa konteks yang kita tidak memilikinya - dan bahwa kontekstualisme memberikan solusi terbaik untuk teka-teki yang dihasilkan oleh argumen skeptis.

\subsection{Koherentisme}

Teori ini mengajarkan bahwa agar suatu keyakinan bisa dibenarkan, maka hal itu harus memiliki sistem kepercayaan yang koheren. Lantas, agar sistem kepercayaan menjadi koheren, maka keyakinan yang membentuk sistem itu harus koheren (cohere) satu sama lain. Biasanya, koherensi dianggap melibatkan tiga komponen, yaitu: konsistensi logis (logical consistency), hubungan penjelas (explanatory relations), dan berbagai hubungan induktif (tidak jelas) atau various inductive (non-explanatory) relations.

\subsection{Teori Campuran}

Ini adalah teori justifikasi yang mengkombinasikan aspek-aspek dari fondasionalisme dan koherentisme.

\section{RINGKASAN}

Klaim kebenaran pengetahuan ilmiah terbuka terhadap pengujian. Terkait hal ini terdapat banyak teori, baik tentang kebenaran maupun justifikasinya. Tentang kebenaran kita mengenal teori korespondensi, koherensi, pragmatis, redundansi, dan semantic. Tentang justifikasi kebenaran kita mengenal teori fondasionalisme, koherentisme, pragmatism, dan teori campuran. Semua teori tersebut dikembangkan untuk menguji bahwa suatu pengetahuan cukup alasan untuk dipercaya sebagai kebenaran.

\section{LATIHAN SOAL}

1. Apa itu kebenaran? Jelaskan!

2. Bilamana 'pengetahuan' manusia dinyatakan 'benar'? Jelaskan! 
3. Jelaskan macam-macam teori tentang kebenaran!

4. Berikan contoh untuk masing-masing teori tersebut!

5. Jelaskan ragam teori tentang bagaimana membuktikan suatu klaim kebenaran!

6. Berikan contoh untuk masing-masing teori tersebut! 


\section{BAB XI}

\section{ETIKA ILMIAH}

\section{PENDAHULUAN}

\subsection{Deskripsi Singkat}

Bab ini mendiskusikan tentang etika ilmiah. Pembahasan mencakup aspek etika pengkajian atau riset ilmiah sekaligus etika seorang ilmuwan dalam melakukan aktivitas ilmiahnya.

\subsection{Relevansi}

Melalui bab ini mahasiswa diharapkan memiliki pemahaman dan wawasan mengenai nilai-nilai yang harus diindahkan dalam dunia ilmu pengetahuan sehingga tidak melakukan atau tergelincir dalam hal-hal yang justru menyelisihi dasar-dasar etis seorang ilmuwan atau praktik ilmiah.

\subsection{Kompetensi Dasar}

a. Mahasiswa mampu menjelaskan pengertian etika ilmiah.

b. Mahasiswa mampu menjelaskan nilai-nilai dasar yang dipedomani dalam dunia ilmu pengetahuan.

c. Mahasiswa mampu menjelaskan kaidah umum (kode etik) yang harus dihormati seorang ilmuwan.

\subsection{Indikator}

a. Mahasiswa dapat menjelaskan pengertian etika ilmiah.

b. Mahasiswa dapat menjelaskan nilai-nilai dasar yang dipedomani dalam dunia ilmu pengetahuan.

c. Mahasiswa dapat menjelaskan kaidah umum (kode etik) yang harus dihormati seorang ilmuwan

\section{ETIKA ILMIAH}

Sebelum membahas lebih luas mengenai apa itu etika ilmiah, perlu dipahami terlebih dahulu beberapa konsep mendasar tentang apa yang dimaksud dengan etika dan kode etik. Dua istilah ini kerap muncul dan tak jarang disalahartikan di antara keduanya.

Etika adalah nilai, konsepsi dan prinsip yang menjadi pedoman moral bagi masyarakat atau individu untuk dapat membedakan perilaku yang baik (memberikan dampak positif bagi manusia, makhluk hidup lain, dan/atau lingkungan) dengan yang buruk (menyebabkan dampak negatif bagi manusia, makhluk hidup lain, dan/atau lingkungan). Maka dari itu, etika ilmiah bisa dipahami sebagai seperangkat nilai, konsepsi, dan 
prinsip yang menjadi pedoman moral untuk membedakan antara perilaku yang baik dan buruk di bidang ilmu pengetahuan. Pengertian ini sekaligus menampik pemahaman bahwa dunia ilmu pengetahuan bersifat bebas nilai.

Sedangkan kode etik adalah pedoman yang digunakan oleh suatu institusi tertentu dalam memandu setiap individu yang bernaung di dalamnya untuk berperilaku baik dan dijadikan landasan keputusan dalam memberikan sanksi bagi individu yang berperilaku buruk. Jadi kode etik di dunia ilmiah bisa merupakan seperangkat pedoman yang mengikat institusi dan atau individu yang ada di dalamnya dalam berperilaku dan berpraktik sebagai seorang ilmuwan.

Salah satu kegiatan ilmiah yang harus menaati prinsip-prinsip nilai etis adalah penelitian atau riset (research). Riset sendiri merujuk pada aktivitas yang memungkinkan kita melakukan pengujian atas suatu hipotesa atau menarik suatu simpulan dan memberi kontribusi bagi pengetahuan, "an activity enabling us to test some hypothesis or to draw conclusions and contribute to knowledge" (Shrader-Frechette, 1994). Setiap penelitian yang dilakukan oleh seorang ilmuwan sudah sepatutnya mematuhi etika riset atau prinsip-prinsip dasar penelitian sebagai berikut:

d. Rasa hormat (Respect). Semua pihak yang terlibat dalam penelitian, baik sebagai informan atau lainnya, harus diperlakukan secara hormat.

e. Konsekuensi baik (Good consequences). Peneliti harus memastikan bahwa aktivitas penelitian yang mereka lakukan akan menghasilkan konsekuensi atau luaran yang baik dan berada dalam batas-batas yang dapat diterima secara moral dan etika.

f. Kejujuran (Fairness). Semua kegiatan penelitian harus didesain dan diimplementasikan secara jujur.

g. Integritas (Integrity). Peneliti harus setia kepada norma-norma yang berlaku serta bertindak secara bertanggung jawab, terbuka dan jujur kepada kolega maupun masyarakat (The Norwegian National Research Ethics Committees, 2014).

Adapun beberapa pedoman umum yang dapat dijadikan sebagai penduan dalam riset ilmiah adalah sebagai berikut:

a. Mencari kebenaran (Quest for truth). Aktivitas penelitian adalah upaya untuk menemukan pengetahuan baru dengan verifikasi sistemik dan kritis serta telaah rekan sejawat. Kejujuran, keterbukaan, sistematisasi dan dokumentasi menjadi prasyarat dasar untuk meraih tujuan ini.

b. Kebebasan akademis (Academic freedom). Institusi penelitian seharusnya membantu guna memastikan bahwa peneliti memiliki kebebasan dalam menentukan pilihan topik dan metodologi, pelaksanaan riset dan publikasi hasil. 
c. Kualitas (Quality). Penelitian seharusnya memiliki kualitas akademis yang tinggi. Peneliti dan lembaga riset sepatutnya memiliki kompetensi yang memadai guna mendesain dan melaksanakan penelitian ilmiah yang berkualitas.

d. Kesediaan tanpa paksaan pihak terkait dalam riset (Voluntary informed consent). Kesediaan merupakan aturan utama dalam riset tentang individua tau tentang informasi dan materi yang dapat dikaitkan dengan individu. Kesediaan ini harus diinformasikan, eksplisit, suka rela tanpa paksaan, dan didokumentasikan. Hal ini juga mengandaikan bahwa pihak yang menyatakan kesediaan adalah seseorang yang memang memiliki kapasitas untuk memberikan suatu pernyataan kesediaan berikut segala konsekuensinya.

e. Kerahasiaan (Confidentiality). Ini juga merupakan prinsip umum bahwa siapa saja yang dijadikan sebagai subyek riset mendapatkan jaminan bahwa informasi pribadi mereka diperlakukan sebagai sesuatu yang harus dijaga kerahasiaannya. Peneliti atau Lembaga riset berkewajiban menjaga dari tiap penggunaan informasi yang dapat merugikan individu atau pihak terkait dengan penelitian.

f. Netralitas (Impartiality). Sikap tidak berpihak berarti menjauhi hal-hal yang dapat membingungkan peran dan hubungan dalam hal mana dapat menimbulkan konflik kepentingan.

g. Integritas (Integrity). Peneliti bertanggung jawab penuh atas kejujuran pribadinya dalam melakukan penelitiannya. Fabrikasi, falsifikasi, plagiasi dan pelanggaran serius sejenisnya atas praktik akademik yang baik adalah hal-hal yang tidak sejalan dengan prinsip kejujuran.

h. Praktik referensi yang baik (Good reference practice). Peneliti perlu memastikan bahwa dirinya mengikuri praktik referensi yang baik yang memenuhi prasyarat lazim untuk verifiabilitas dan dasar bagi riset lanjutan.

i. Kolegial (Collegiality). Para peneliti harus menunjukkan rasa dan sikap saling menghormati. Mereka harus setuju dan patuh pada praktik-praktik baik terkait kepemilikan dan berbagi data, authorship, publikasi, peer review, dan kerjasama lainnya secara umum.

j. Tanggung jawab kelembagaan (Institutional responsibility). Tanggung jawab atas tindakan etis tidak hanya dibebankan kepada individu peneliti, tetapi juga lembaga riset. Maka dari itu, Lembaga wajib memastikan bahwa suatu riset dilaksanakan sesuai dengan praktik akademik yang baik dan tidak melanggar norma-norma riset yang etis.

k. Ketersediaan hasil (Availability of results). Sebagai aturan utama juga, hasil dari penelitian seharusnya dapat diakses atau tersedia untuk publik. Keterbukaan ini mendasar guna memastikan verifiabilitas, mengembalikan manfaat kepada partisipan riset dan masyarakat secara umum, serta memungkinkan adanya dialog. 
I. Tanggung jawab social (Social responsibility). Peneliti memiliki tanggung jawab untuk memastikan bahwa riset mereka akan memberi manfaat bagi pihak terkait serta tidak menyebabkan kerugian atau bahaya.

m. Tanggung jawab global (Global responsibility). Pengetahuan hasil penelitian juga sedianya harus diinformasikan kepada seluruh khalayak sehingga tidak ada pihak yang terkecualikan termasuk mereka yang secara ekonomi memiliki keterbatasan. Dalam hal ini pengetahuan memiliki fungsi melawan ketidakadilan global dan juga memelihara keragaman biologis.

n. Hukum dan peraturan (Laws and regulations). Penelitian harus dilakukan dengan memperhatikan hokum dan peraturan yang berlaku baik di tingkat lokal maupun global (The Norwegian National Research Ethics Committees, 2014).

\section{KODE ETIK ILMUWAN}

Dari paparan dalam sub bab di atas sebenarnya sudah tergambar mengenai garis-garis besar kaidah yang harus diikuti dan dipatuhi oleh setiap ilmuwan atau orang-orang yang bergelut di bidang ilmu pengetahuan. Secara umum, seorang ilmuwan haruslah, pertama, berpegang pada prinsip-prinsip etika ilmiah yang diterima secara universal; dan kedua, mematuhi pedoman-pedoman keilmuan yang diterima secara umum atau yang ditetapkan oleh otoritas yang legal dan berintegritas.

Justru hal yang kerap terabaikan adalah hal-hal apa saja yang seharusnya dijauhi dan tidak dilakukan oleh seorang ilmuwan di bidang ilmu pengetahuan ini. Beberapa uraian berikut bisa menjelaskannya:

a. Ilmuwan tidak sepatutnya secara sengaja mengabaikan atau mengaburkan atau tidak melakukan penyebutan dalam bentuk sitasi atas karya-karya terdahulu yang berkontribusi dalam karyanya (Intentional negligence in the acknowledgment of previous work), bahkan termasuk karyanya sendiri yang terdahulu.

b. Ilmuwan juga sangat diharamkan melakukan fabrikasi secara sengaja dan disadari atas data-data yang ia kumpulkan (deliberate fabrication of data you have collected).

c. Ilmuwan tidak diizinkan melakukan secara sadar dan sengaja meniadakan atau menghilangkan data yang ditemukan dan tidak dikehendakinya hanya semata agar simpulan riset sesuai dengan hipotesa yang dikembangkannya (deliberate omission of known data that does not agree with the hypothesis).

d. Ilmuwan dilarang keras menggunakan atau memakai data milik peneliti atau ilmuwan lain dengan membuat pengakuan palsu bahwa data tersebut adalah miliknya (passing another researcher's data as one's own).

e. Ilmuwan juga tidak dibenarkan melakukan publikasi hasil tanpa ada persetujuan atau kesediaan dari semua pihak yang terlibat (publication of results without the consent of all of the researchers). 
f. Ilmuwan juga tidak sepatutnya melakukan kesalahan dengan tidak memberikan pengakuan dengan cara misalnya tidak menyebut peneliti yang sudah terlibat dalam penelitiannya secara patut dan layak (failure to acknowledge all of the researchers who performed the work).

g. Ilmuwan tidak boleh memiliki konflik kepentingan dalam risetnya (conflict of interest).

h. Ilmuwan dilarang melakukan publikasi berulang atas hasil riset atau review yang mirip atau bahkan sama (repeated publication of too-similar results or reviews).

i. Ilmuwan sangat-sangat dilarang membocorkan rahasia (breach of confidentiality).

j. Ilmuwan juga tidak dibenarkan melakukan ketidakpatutan dalam menyajikan karya terdahulu milik orang lain (misrepresenting others' previous work) (D’Angelo, 2012).

Dari sini menjadi semakin jelas bahwa etos sains menuntut hubungan yang hati-hati antara ilmuwan, data yang mereka peroleh atau sajikan, serta komunitas para peneliti atau ilmuwan. Mengapa demikian? Karena harus diinsyafi bahwa sains pada dasarnya adalah aktivitas komunal, dan karenanya maka ilmuwan harus secara hati-hati melakukan tugasnya mula dari perumusan hipotesa, pengujian, pencatatan proses, pemberian pengakuan kontribusi semua pihak yang terlibat, hingga penyajian sampai pada bentuk simpulan (Koepsell, 2017). Semangat atau etos ilmiah ini wajib dimiliki oleh setiap ilmuwan.

\section{RINGKASAN}

Seorang ilmuwan sudah seharusnya mematuhi prinsip-prinsip etika ilmiah serta kode etik ilmuwan dalam melakukan tugas dan praktik profesionalnya. Dunia ilmu pengetahuan tidak lepas dari prinsip-prinsip etika baik dari cara pemerolehan, pembahasan, publikasi atau pendistribusian informasi, serta pemakaiannya. Ilmu tidak bebas dari prinsip-prinsip etis.

\section{LATIHAN SOAL}

1. Jelaskan apa yang dimaksud dengan etika ilmiah!

2. Mengapa etika ilmiah harus ditegakkan? Jelaskan!

3. Sebutkan dan jelaskan nilai-nilai dasar yang harus dihormati dan diindahkan oleh seorang ilmuwan dalam praktik ilmiah! 


\section{DAFTAR PUSTAKA}

Ahmad Tafsir. 1990. Filsafat Umum. Bandung: Rosdakarya.

Bertens. 1966. Filsafat Dewasa ini. Ter. Hasan Amin. Jakarta: Balai Pustaka.

Bryan Magee. 2008. The Story if Philosophy: Panorama Filsafat. Ter. Marcus Widodo \& Hardono Hadi. Yogya: Kanisius,

Charles J. Braunes \& Hobert W. Burns. 1965.Problems in Education and Philosophy. New York: Prentice-Hall Inc.

Charles J. Braunes \& Hobert W. Burns. 1965. Problems in Education and Philosophy. New York: Prentice-Hall Inc.

Copelston. History of Philosophy.

D'Angelo, J. 2012. Ethics in Science: Ethical Misconduct in Scientific Research. Boca Raton, London, NY: CRC Press.

Drew Westen. Psychology: Mind, Brain, and Culture.

Endang Saifuddin Ansori. 1981. Ilmu Filsafat dan Agama. Surabaya: Bina Ilmu.

G. Lee Bowie, Meredith W. Michaels dan Robert C. Solomon. Twenty Questions: An Introduction to Philosophy.

H.M. Rasyidi. 1970. Filsafat Agama. Jakarta: t.p.

Harry Hamersma. Pintu Masuk ke Dunia Filsafat.

Huff, T.E. 2003. The Rise of Early Modern Science: Islam, China, and the West. Cambridge: Cambridge University Press.

I.R. Poedjawijatna. Tahu dan Pengetahuan: Pengantar ke Ilmu dan Filsafat. . 1974. Pembimbing ke Arah Alam Filsafat. Jakarta: Pembangunan.

J. Sudarminta. Epistemologi Dasar: Pengantar Filsafat Pengetahuan.

Jan Hendrik Rapar. Pengantar Filsafat.

John Shand. Philosophy and Philosophers: An Introduction to Western Philosophy.

Jujun S. Suria Sumantri. 1993. Filsafat Ilmu Sebagai Pengantar Populer. Jakarta: Pustaka Sinar Harapan.

Kenneth T. Gallagher. Epistemologi: Filsafat Pengetahuan.

Koepsell, D. 2017. Research Integrity and Research Ethics: An Approach from the Ethos of Science. Switzerland: Springer.

Louis Kattsof. Pengantar Filsafat.

Mudlor Achmad. Manusia dan Kebenaran: Masalah Pokok Filsafat.

Muhammad Hatta. 1969. Alam Pikiran Yunani. Jakarta: Tintamas.

Okasha, S. 2002. Philosophy of Science: A Very Short Introduction. Oxford: Oxford University Press.

Oong Komar. Filsafat Ilmu dan Pendidikan.

P. H. Hirst \& R. S. Peters. 1972. The Logic of Education. London: Routledge \& Kegan Paul.

Partap Sing Mehra dan Jazir Burhan. Pengantar Logika Tradisional.

Poedjawijatna, I.R.. 1991. Tahu dan Pengetahuan: Pengantar ke Ilmu dan Filsafat. Rineka Cipta. 
Poedjawijatna, I.R.. Logika: Filsafat Berfikir.

Pollock, J.L. \& Cruz, J. 1987. Contemporary Theories of Knowledge.

Redja Mudyahardjo. Filsafat Ilmu Pendidikan: Suatu Pengantar.

Robert Audi, Epistemology: A Contemporary Introduction to the Theory of Knowledge, Second Edition (New York \& London: Routledge, 2003)

Robert C. Solomon \& Kathleen M. Higgins. Sejarah Filsafat.

Rosenberg, A. 2012. A Philosophy of Science: A Contemporary Introduction. NY \& London: Routledge.

Shrader-Frechette, K. 1994. Ethics of Scientific Research Issues in Academic Ethics. Lanham: Rowman \& Littlefield Publishers, Inc.

Stephen Palmquist. Filsafat Mawas: Kuliah Filsafat Umum untuk Pemula.

Sudarminta, J. 2002. Epistemologi Dasar: Pengantar Filsafat Pengetahuan. Kanisius.

Surajiyo. Ilmu Filsafat: Suatu Pengantar.

Sutardjo A. Wiramihardja. Pengantar Filsafat: Sistematika Filsafat, Sejarah Filsafat, Logika dan Filsafat IImu (Epistemologi), Metafisika dan Filsafat Manusia, Aksiologi.

Sutarjo Adisusilo. 2007. Sejarah Pemikiran Barat. Yogya: USD.

Tafsir, A. Filsafat Ilmu: Mengurai Ontologi, Epistemologi, dan Aksiologi Pengetahuan.

The Liang Gie. Pengantar Filsafat IImu.

The Norwegian National Research Ethics Committees. 2014. General Guidelines for Research Ethics. URL: https://www.etikkom.no/globalassets/general-guidelines.pdf.

Walker, R. C. S. (2017). Theories of Truth: A Companion to the Philosophy of Language, 532-555. DOI:10.1002/9781118972090.ch21

Wiramihardja, S.A. 2009. Pengantar Filsafat: Sistematika Filsafat, Sejarah Filsafat, Logika dan Filsafat IImu (Epistemologi), Metafisika dan Filsafat Manusia, Aksiologi.

Yuhaya S. Praja. 1997. Pengantar Filsafat IImu: Filsafat IImu-IImu Islam. Bandung: PPS IAIN SGD. 


\section{PENULIS}

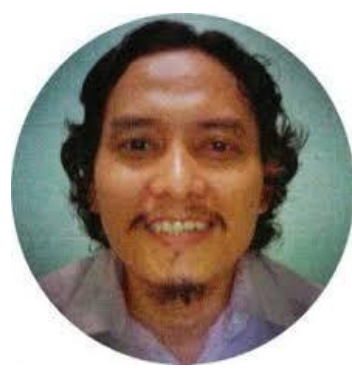

Dr. Nyong Eka Teguh Iman Santosa, M.Fil.I. lahir di Sidoarjo, 22 Desember 1976. Pendidikan dasar dan menengah ditempuh di kota kelahirannya: SDN Punggul 2 (1983-1989), SMPN 1 Sidoarjo (1989-1992), dan SMAN 1 Sidoarjo (1992-1995). Sebelum melanjutkan studi kesarjanaan, sempat mengenyam kehidupan pesantren di Al-Irsyad, Tengaran, Semarang selama 3 tahun (1995-1998). Pada tahun 2003, penulis mendapatkan gelar Sarjana Pendidikan Islam (S.Pd.I.) dari Universitas Muhammadiyah Sidoarjo (UMSIDA). Penulis melanjutkan studi S2 dengan konsentrasi pemikiran Islam di IAIN (sekarang UIN) Sunan Ampel Surabaya. Tahun 2005, penulis secara resmi mendapatkan gelar Magister Filsafat Islam (M.Fil.I.). Pendidikan doktoral penulis tempuh di the Indonesian Consortium for Religious Studies (ICRS), sebuah program internasional bidang studi lintas agama (an international Ph.D. program in Inter-Religious Studies) yang dikelola oleh tiga perguruan tinggi di Yogyakarta: Universitas Gadjah Mada (UGM), UIN Sunan Kalijaga, dan Universitas Kristen Duta Wacana (UKDW). GelarDoktor (Dr.) penulis raih di awal tahun 2017. Penulis mengawali karirnya sebagai pendidik di UMSIDA sebagai asisten dosen (Alm. Dr. Abdul Hamid, M.Ag.) di awal tahun akademik 2003/2004. Tahun berikutnya diangkat sebagai Dosen LB di Fakultas Tarbiyah (sekarang Fakultas Agama Islam) UMSIDA. Pada tahun 2006 penulis diangkat sebagai Dosen Fakultas Ushuluddin (sekarang Fakultas Ushuluddin dan Filsafat) UIN Sunan Ampel Surabaya yang diperbantukan (DPK) di UMSIDA. Fokus kajian dan riset penulis adalah tentang filsafat dan sejarah peradaban Islam. 